Final Report

FHWA/IN/JTRP-2006/6

\title{
The Effectiveness and Criteria for Placement of Raised Pavement Markers (Synthesis Study)
}

\author{
By \\ Yi Jiang, Ph.D., P.E. \\ Associate Professor \\ Department of Building Construction Management \\ Purdue University \\ Joint Transportation Research Program \\ Project No. C-36-59SS \\ File No. 8-5-45 \\ SPR-2949 \\ Conducted in Cooperation with the \\ Indiana Department of Transportation \\ and the U.S. Department of Transportation \\ Federal Highway Administration
}

The contents of this report reflect the views of the author who is responsible for the facts and accuracy of the data presented herein. The contents do not necessarily reflect the official views or policies of the Indiana Department of Transportation and Federal Highway Administration. This report does not constitute a standard, specification, or regulation.

Purdue University

West Lafayette, Indiana

October 2006 


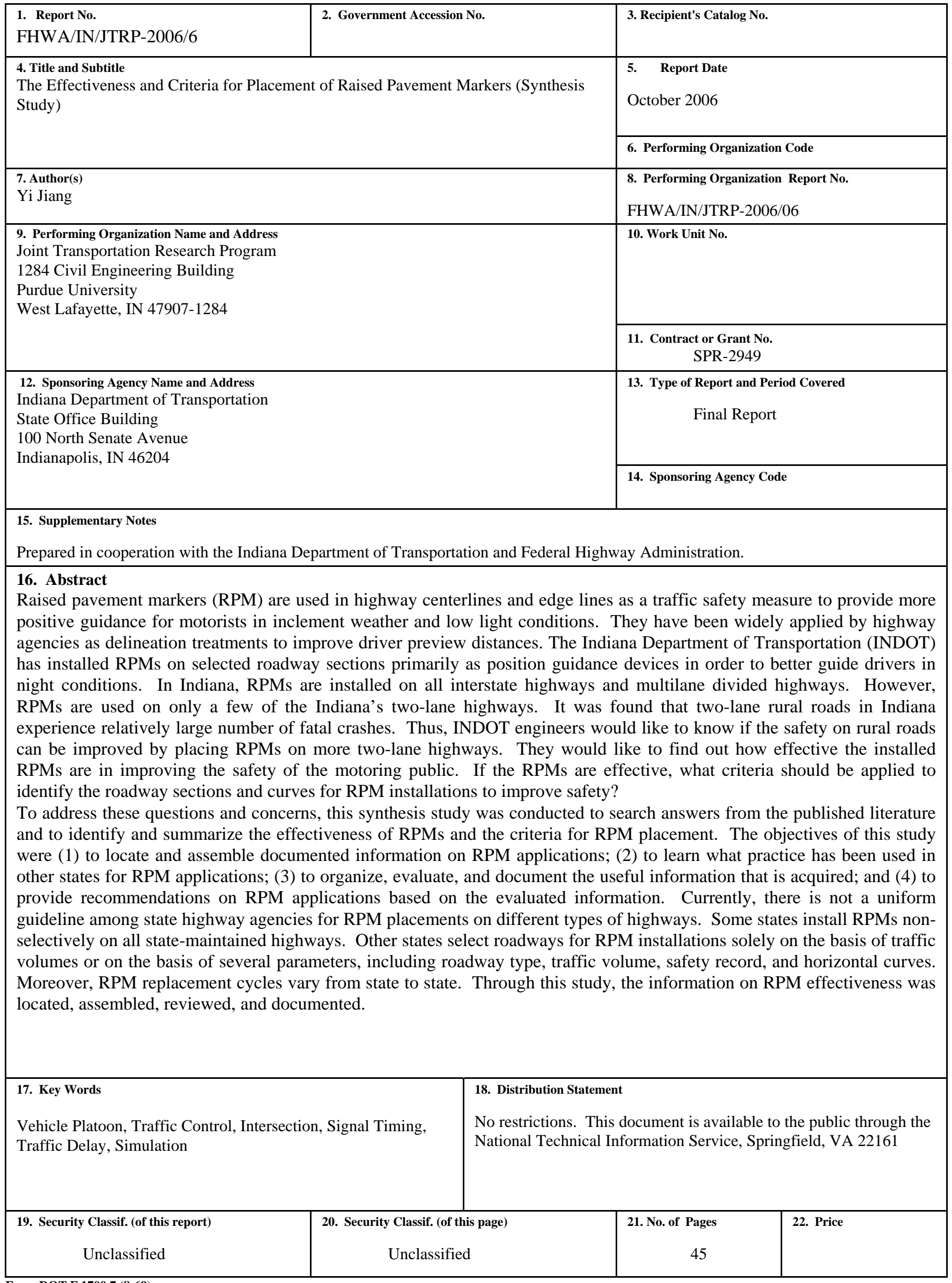




\section{ACKNOWLEDGMENTS}

This research project was sponsored by the Indiana Department of Transportation (INDOT) in cooperation with the Federal Highway Administration through the Joint Transportation Research Program. The author would like to thank the study advisory committee members, Shuo Li, John Nagle, Dwayne Harris, Bob Bienversie, Carl Tuttle, Sami Mohamid, Eric Rader, Terry Summers, Dave Ellis, and Rick Drumm, for their valuable assistance and technical guidance. Mr. Dave Ellis and several engineers from the INDOT Districts provided information on the current practices of placing and maintaining raised pavement markers in Indiana. Their efforts and useful inputs are acknowledged and every much appreciated. 


\section{TABLE OF CONTENTS}

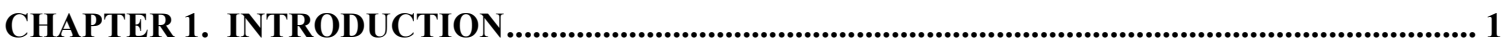

CHAPTER 2. THE EFFECTS OF RAISED PAVEMENT MARKERS ON ROADWAY SAFETY .. 4 CHAPTER 3. THE STATE OF PRACTICE OF RAISED PAVEMENT MARKER

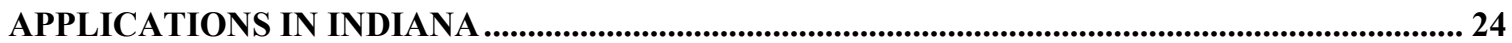

CHAPTER 4. CONCLUSIONS AND RECOMMENDATIONS ........................................................ 37

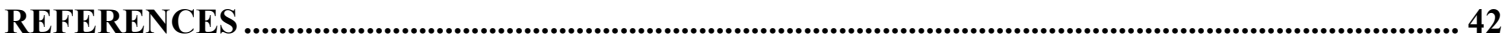

APPENDIX A: MEMORANDUM 96-02 - SNOWPLOWABLE RAISED PAVEMENT MARKERS

GUIDELINES FOR INSTALLATION AT NEW LOCATION ......................................................... 44

APPENDIX B: MEMORANDUM 96-03 - SNOWPLOWABLE RAISED PAVEMENT MARKERS

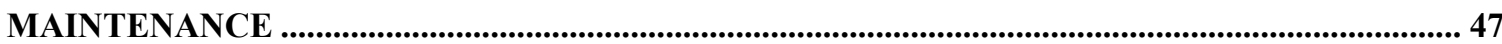




\section{LIST OF TABLES}

Table 1. Test Sites Features of the Tennessee Study (Hammond and Wegmann, 2001) .. 5

Table 2. Minimum Retroreflectivity for Pavements with and without Raised Pavement

Markers (Zwahlen and Schnell, 2000) ................................................................ 7

Table 3. Summary of literature on the safety effectiveness of RPMs ............................ 16

Table 4. RPM guidelines based on traffic volume for different roadway types ............... 19

Table 5. RPM replacement cycles for the state of Indiana ........................................... 19

Table 6. When to schedule RPM system maintenance for the state of Texas ................ 19

Table 7. Suggested replacement cycles for RPMs for the state of Texas ....................... 19

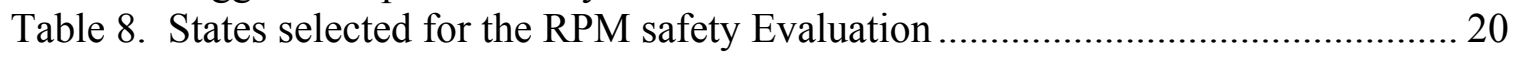

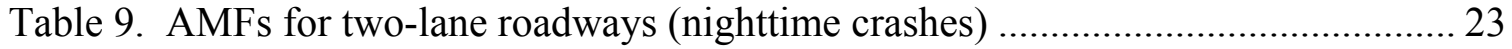

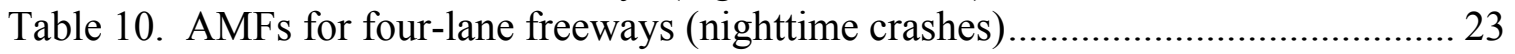

Table 11. Questionnaire Survey Results - Greenfield District..................................... 26

Table 12. Questionnaire Survey Results - Seymour District ...................................... 27

Table 13. Questionnaire Survey Results - Vincennes District ..................................... 29

Table 15. Questionnaire Survey Results - Fort Wayne District ................................... 33

Table 16. Questionnaire Survey Results - LaPort District ......................................... 34

Table 17. Questionnaire Survey Results - Toll Road District...................................... 36 


\section{LIST OF FIGURES}

Figure 1. Test Site Layout of the Tennessee Study ....................................................... 5

Figure 2. Product Information of the Maryland Evaluation Study ................................. 8

Figure 3. Graphs of Retroreflectivity - MD-100 .................................................... 9

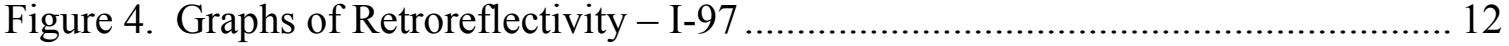




\section{CHAPTER 1. INTRODUCTION}

Raised pavement markers (RPM) are used in highway centerlines and edge lines as a traffic safety measure to provide more positive guidance for motorists in inclement weather and low light conditions. They have been widely applied by highway agencies as delineation treatments to improve driver preview distances. Generally, there are three different uses for raised pavement markers: 1) as a substitute for painted lines, 2) supplementing painted lines, and 3) as position guidance devices. The Indiana Department of Transportation (INDOT) has installed RPMs on selected roadway sections primarily as position guidance devices in order to better guide drivers in night conditions. In Indiana, RPMs are installed on all interstate highways and multilane divided highways. However, RPMs are used on only a few of the Indiana's two-lane highways. It was found that two-lane rural roads in Indiana experience relatively large number of fatal crashes. Thus, INDOT engineers would like to know if the safety on rural roads can be improved by placing RPMs on more two-lane highways. They would like to find out how effective the installed RPMs are in improving the safety of the motoring public. If the RPMs are effective, what criteria should be applied to identify the roadway sections and curves for RPM installations to improve safety?

To address these questions and concerns, this synthesis study was conducted to search answers from the published literature and to identify and summarize the effectiveness of RPMs and the criteria for RPM placement. The objectives of this study were (1) to locate and assemble documented information on RPM applications; (2) to learn what practice has been used in other states for RPM applications; (3) to organize, 
evaluate, and document the useful information that is acquired; and (4) to provide recommendations on RPM applications based on the evaluated information. Currently, there is not a uniform guideline among state highway agencies for RPM placements on different types of highways. Some states install RPMs non-selectively on all statemaintained highways. Other states select roadways for RPM installations solely on the basis of traffic volumes or on the basis of several parameters, including roadway type, traffic volume, safety record, and horizontal curves. Moreover, RPM replacement cycles vary from state to state. Through this study, the information on RPM effectiveness was located, assembled, reviewed, and documented. Efforts were made in this study to address INDOT engineers' specific concerns and questions, including the different uses of RPMs and replacement of RPM parts.

In order to fulfill the objective of the proposed project, the research work focused on the following areas and tasks:

(1) Summarize INDOT's practice of RPM placement. A questionnaire survey was conducted to obtain the information from the INDOT districts on the criteria of INDOT districts for RPM placement, maintenance and replacement.

(2) Literature review was performed to locate, assemble, review, and document studies, technical reports and papers, and other information on RPM applications, criteria, and effectiveness. There exist many publications on RPM evaluations, including RPM effect on safety at horizontal curves and rural highways, RPM reflectance, computer-based modeling of RPM visibility, RPM spacing, and driver behavior on roads with RPMs. These publications were identified, obtained, and carefully reviewed. 
(3) The acquired information was organized and evaluated. Information pertinent to RPM installation criteria, effectiveness, and positive and negative impact on safety was gathered and compiled. 


\section{CHAPTER 2. THE EFFECTS OF RAISED PAVEMENT MARKERS ON ROADWAY SAFETY}

A number of research and evaluation projects have been conducted by researchers in several states. These studies analyzed the positive and negative impacts of raised pavement markers on highway safety in various respects, including daytime, nighttime, marker spacing, and roadway curves. The major studies and their findings are discussed as follows.

Hammond and Wegmann (2001) studied the effects of raised pavement markers on horizontal curves during daytime in Knoxville, Tennessee. The layout and test site features are shown in Table 1 and Figure 1. In their study, the encroachment distances before and after the installation of raised pavement markers at 40-ft (12-m) spacing were measured. Then additional raised pavement markers were added to the roadway to change the spacing from 40 feet $(12-\mathrm{m})$ to 20 feet $(6-\mathrm{m})$. The encroachment distances after the installation of additional raised pavement markers were measured. The average operating speeds throughout the length of the curve before and after the raised pavement marker application were also recorded during encroachment measurements. The raised pavement markers utilized in the study were non-plowable raised pavement marker (Stimsonite LifeLite $88 \mathrm{~A})$ with a dimension of 4 in. $x 4$ in. $x 0.70$ in. $(10 \mathrm{~cm} \times 10 \mathrm{~cm} \times 2$ $\mathrm{cm})$. The color of the markers was standard amber as prescribed by the Manual on Uniform Traffic Control Devices (1988). The markers were placed in pairs on two sides of the painted centerline. 
Table 1. Test Sites Features of the Tennessee Study (Hammond and Wegmann, 2001)

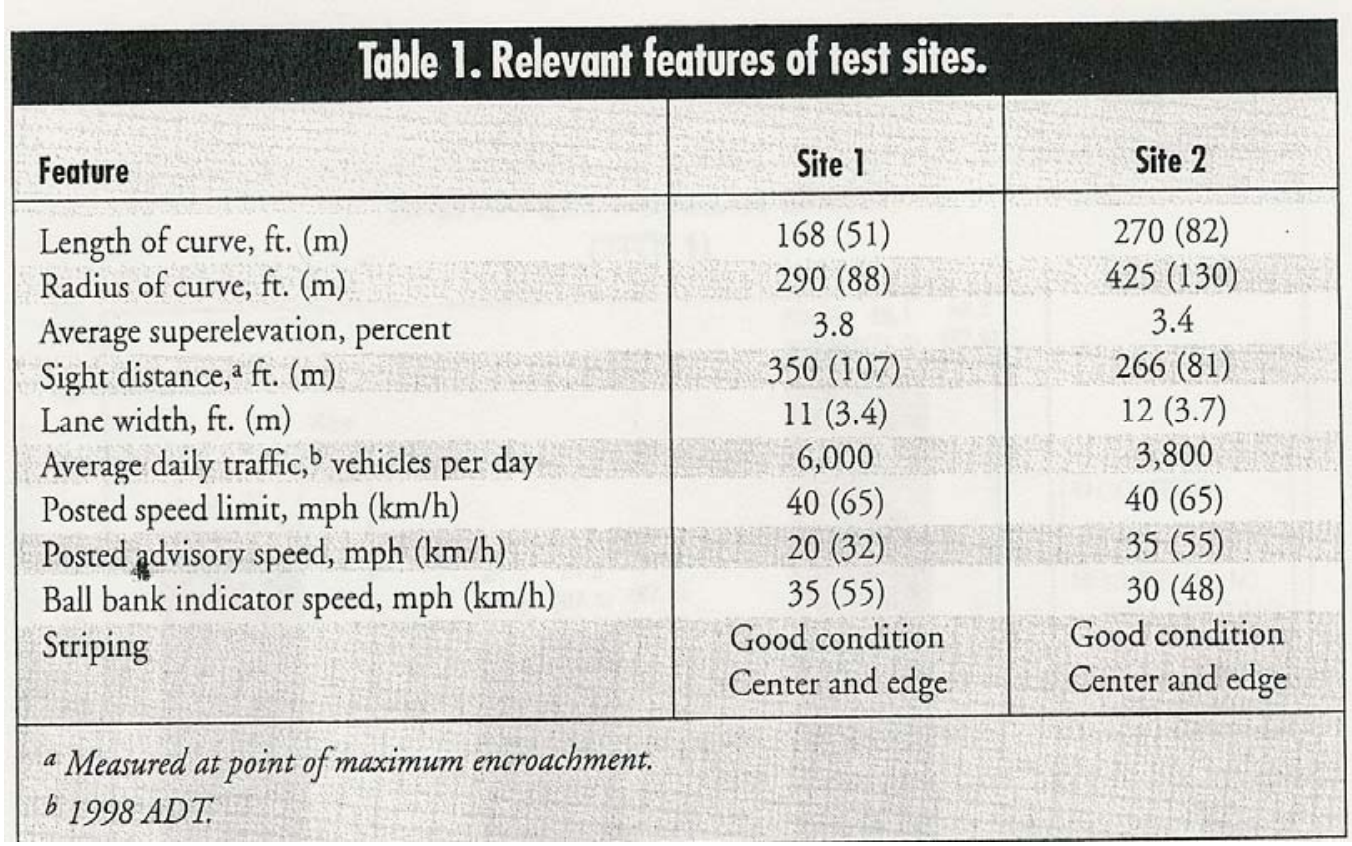

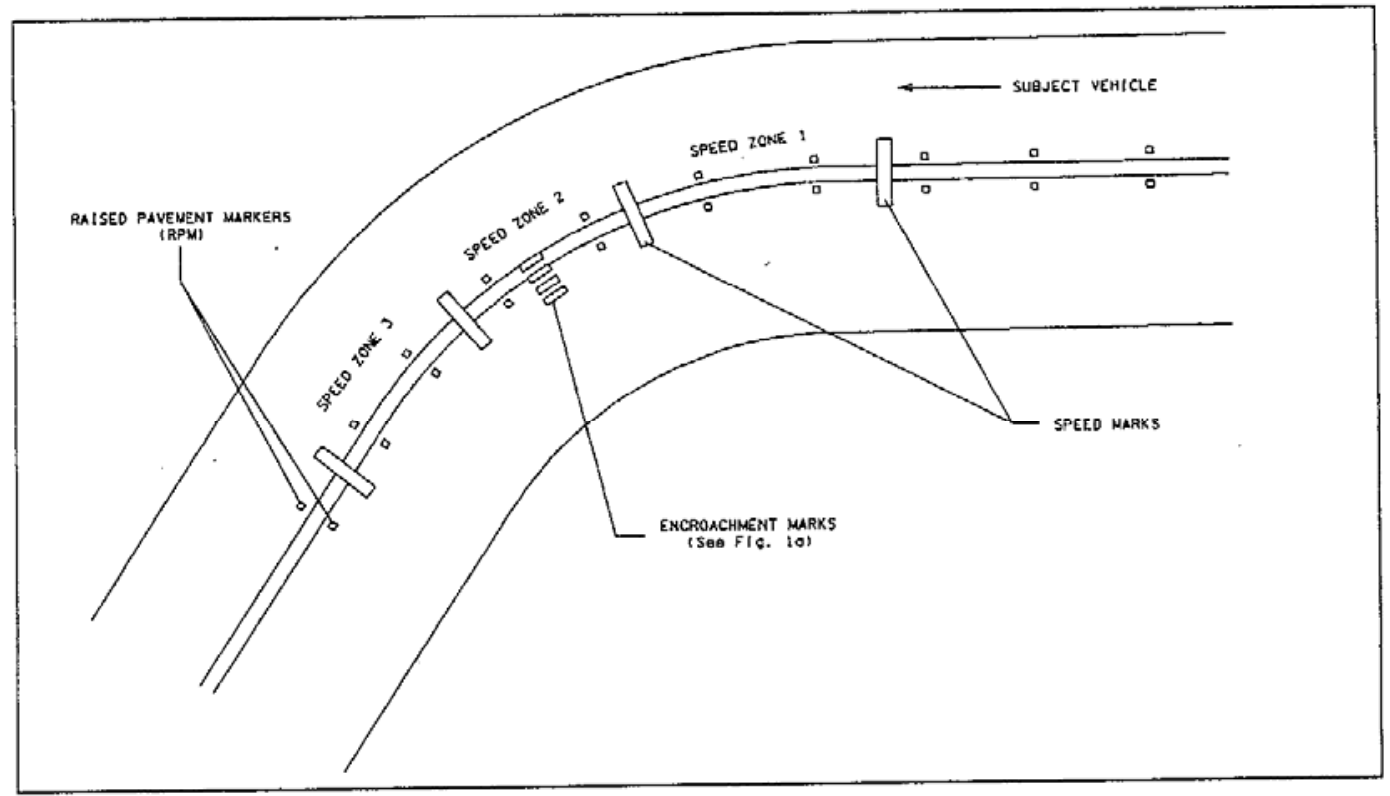

Fiqure 1. Test-site configuration.

Figure 1. Test Site Layout of the Tennessee Study (Hammond and Wegmann, 2001) 
The Tennessee study produced the following findings:

- The raised pavement markers did not affect vehicle speed significantly.

- The levels of encroachment (LEs) were grouped into: high (LE 6 to 8 inches), moderate (LE 3 to 5) and low (LE 0 to 2). The mean LE was 3.3 for the control condition (before installation of the raised pavement markers), 2.5 for the $40-\mathrm{ft}$ spacing condition, and 2.1 for the 20 -ft spacing. The reduction in encroachment from the control condition to the $40-\mathrm{ft}$ spacing condition was statistically significant. But the reduction from $40-\mathrm{ft}$ spacing to the $20-\mathrm{ft}$ spacing was not statistically significant.

The findings indicate that the raised pavement markers had positive effect on highway safety on horizontal roadway curves during daytime.

A study conducted by Ohio University (Zwahlen and Schnell, 2000) analyzed the minimum retroreflectivity of pavement paint markings with and without installation of raised pavement markers. The major result of the Ohio study is that the minimum retroreflectvity requirements for pavement markings can be substantially relaxed if raise pavement markers were installed alongside painted edge lines, centerlines, and/or lane lines. As shown in Table 2, the minimum required retroreflected luminance for painted pavement lines can be reduced significantly by placing raised pavement markers along the painted lines when vehicle speed is greater than $25 \mathrm{mph}$. This means that the pavements with raised pavement markers do not need to repaint pavement markings as often as those pavements without raised pavement markers. Therefore, the prolonged 
intervals between repainting times would result in savings for pavement markings, which would compensate for some of the cost of raised pavement markers.

Table 2. Minimum Retroreflectivity for Pavements with and without Raised Pavement Markers (Zwahlen and Schnell, 2000)

\begin{tabular}{|c|c|c|c|}
\hline & & $\begin{array}{l}\text { Minimum Required Re } \\
{\left[\mathrm{mcd} / \mathrm{m}^{2} / \mathrm{lx}\right] \text { for Fully } \mathrm{N}} \\
\text { Two White Edgelines a } \\
\text { Lane Line }\end{array}$ & $\begin{array}{l}\text { eflected Luminance }\left(R_{L}\right) \\
\text { ed Roads Consisting of } \\
\text { Dashed Yellow/White }\end{array}$ \\
\hline $\begin{array}{c}\text { Vehicle } \\
\text { Speed (mph) }\end{array}$ & $\begin{array}{c}\text { Vehicle } \\
\text { Speed }(\mathrm{km} / \mathrm{h})\end{array}$ & $\begin{array}{c}\text { Without RPMs, } \\
\text { Preview Time }=3.65 \mathrm{~s}\end{array}$ & $\begin{array}{c}\text { With RPMs, } \\
\text { Preview Time }=2.0 \mathrm{~s}\end{array}$ \\
\hline $0-25$ & $0-40$ & 30 & 30 \\
\hline $26-35$ & $41-56$ & 50 & 30 \\
\hline $36-45$ & $57-72$ & 85 & 30 \\
\hline $46-55$ & $73-88$ & 170 & 35 \\
\hline $56-65$ & 89-104 & 340 & 50 \\
\hline $66-75$ & $105-120$ & 620 & 70 \\
\hline
\end{tabular}

A Maryland study (Stellfox, 2004) evaluated seven types of snowplowable raised pavement markers. The product information is listed in Figure 2. Retroreflectivity readings were collected using Model 1200SP Retroreflectometers, manufactured by Gamma Scientific of San Diego, California. For each installed raised pavement marker, retroreflectivity was measured twice, one is the "dirty reading" and the other is the "clean reading". A dirty reading is measured first and then the marker lens was cleaned before a clean reading was made. The retroreflectivity values measured during the two-year evaluation period are shown in Figures 3 and 4. The graphs in Figures 3 and 4 indicate that after two years the raised pavement markers lost more than $50 \%$ of their retroreflectivities for both dirty and clean readings. 
Figure 2. Product Information of the Maryland Evaluation Study (Stellfox, 2004)

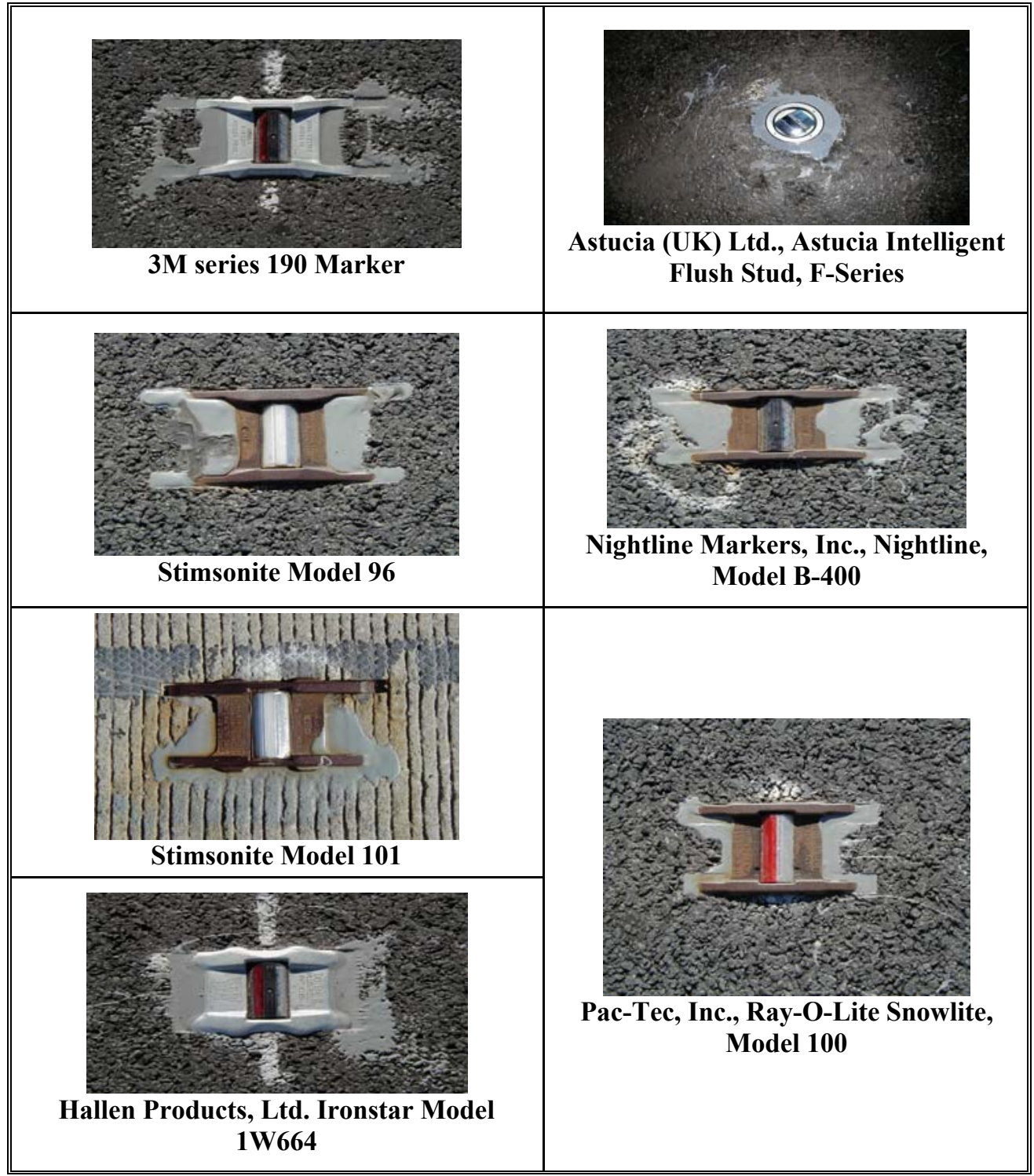


Figure 3. Graphs of Retroreflectivity - MD-100 (Stelffox, 2004)
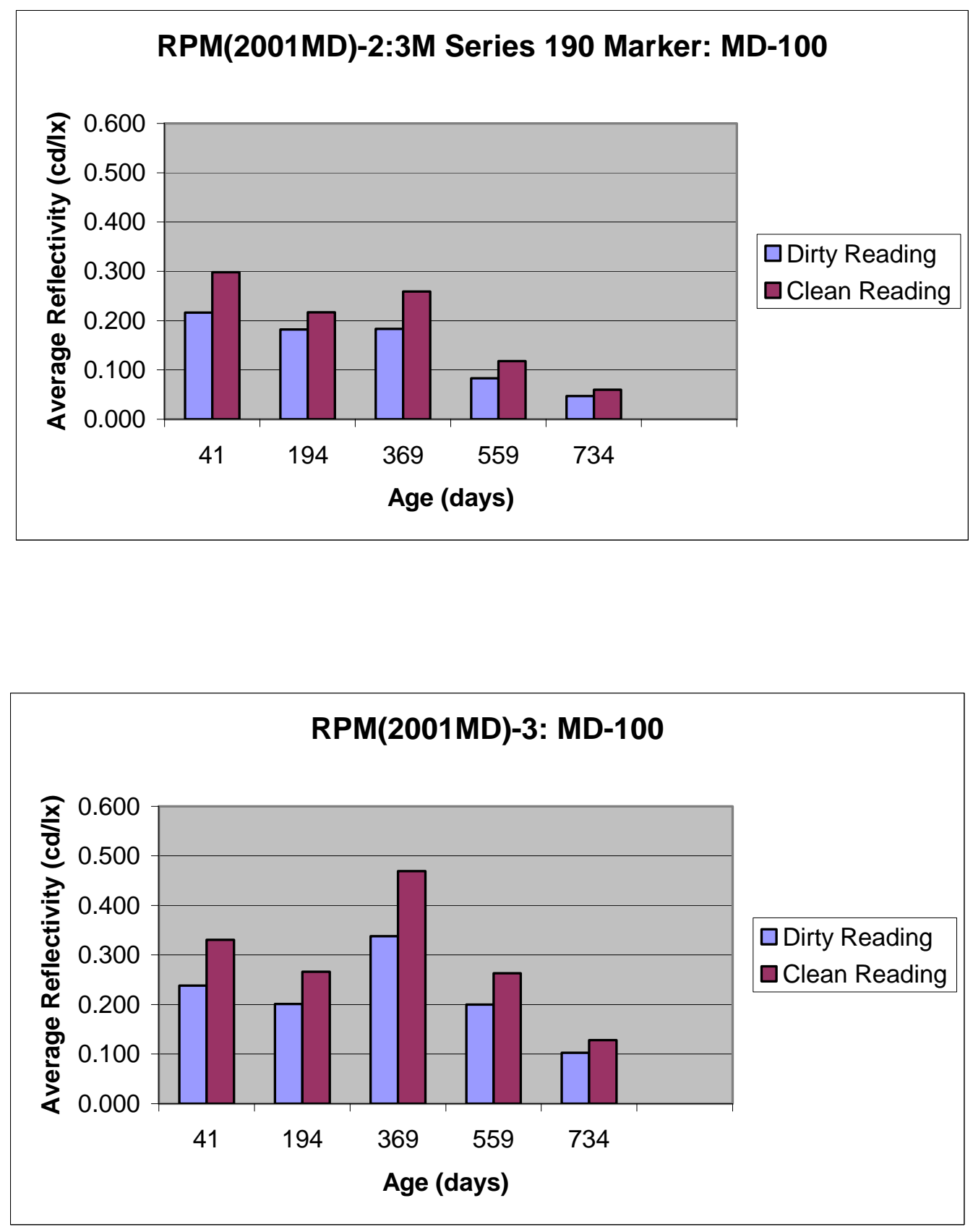
Figure 3. Graphs of Retroreflectivity - MD-100 (continued) (Stellfox, 2004)
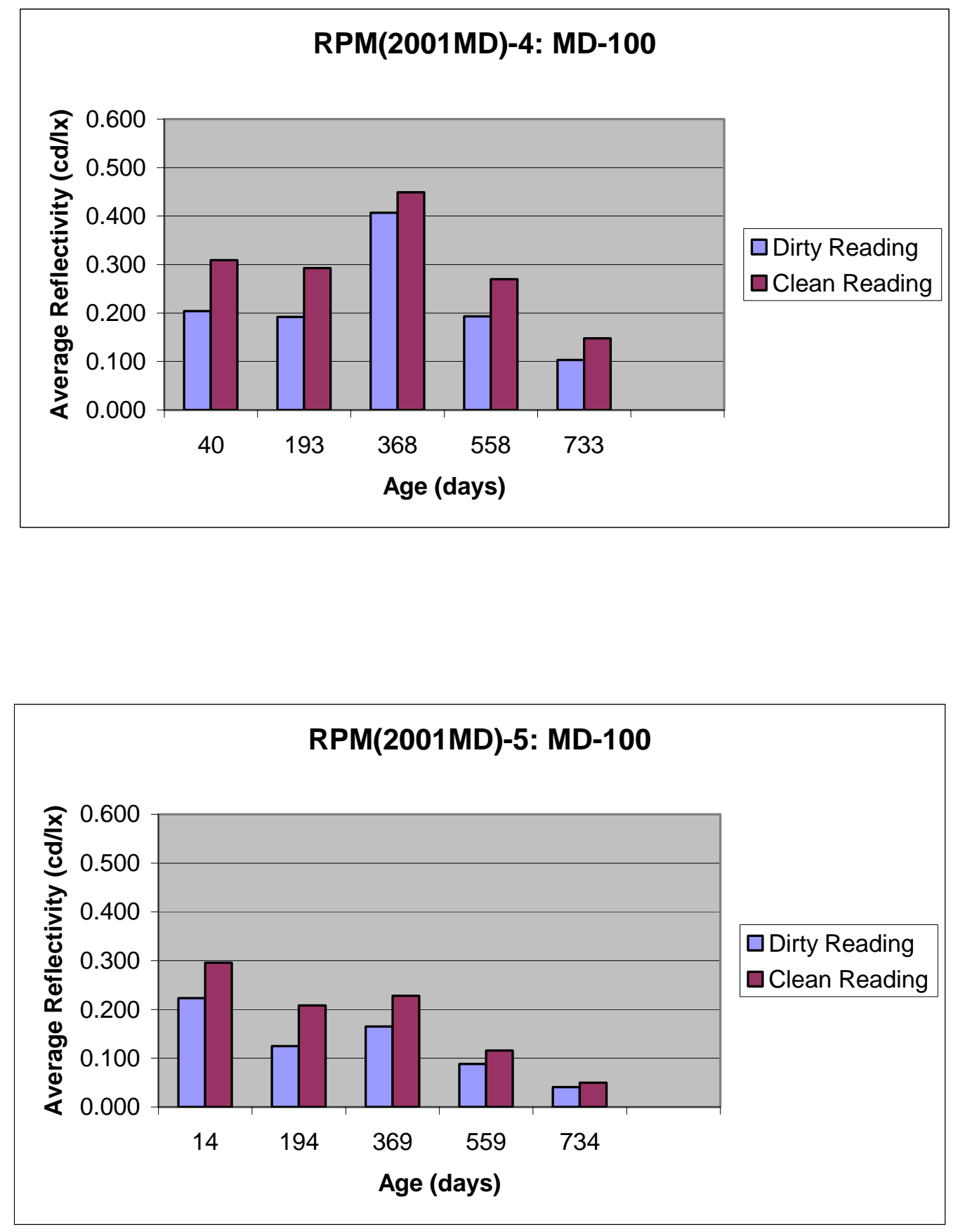
Figure 3. Graphs of Retroreflectivity (continued) (Stellfox, 2004)

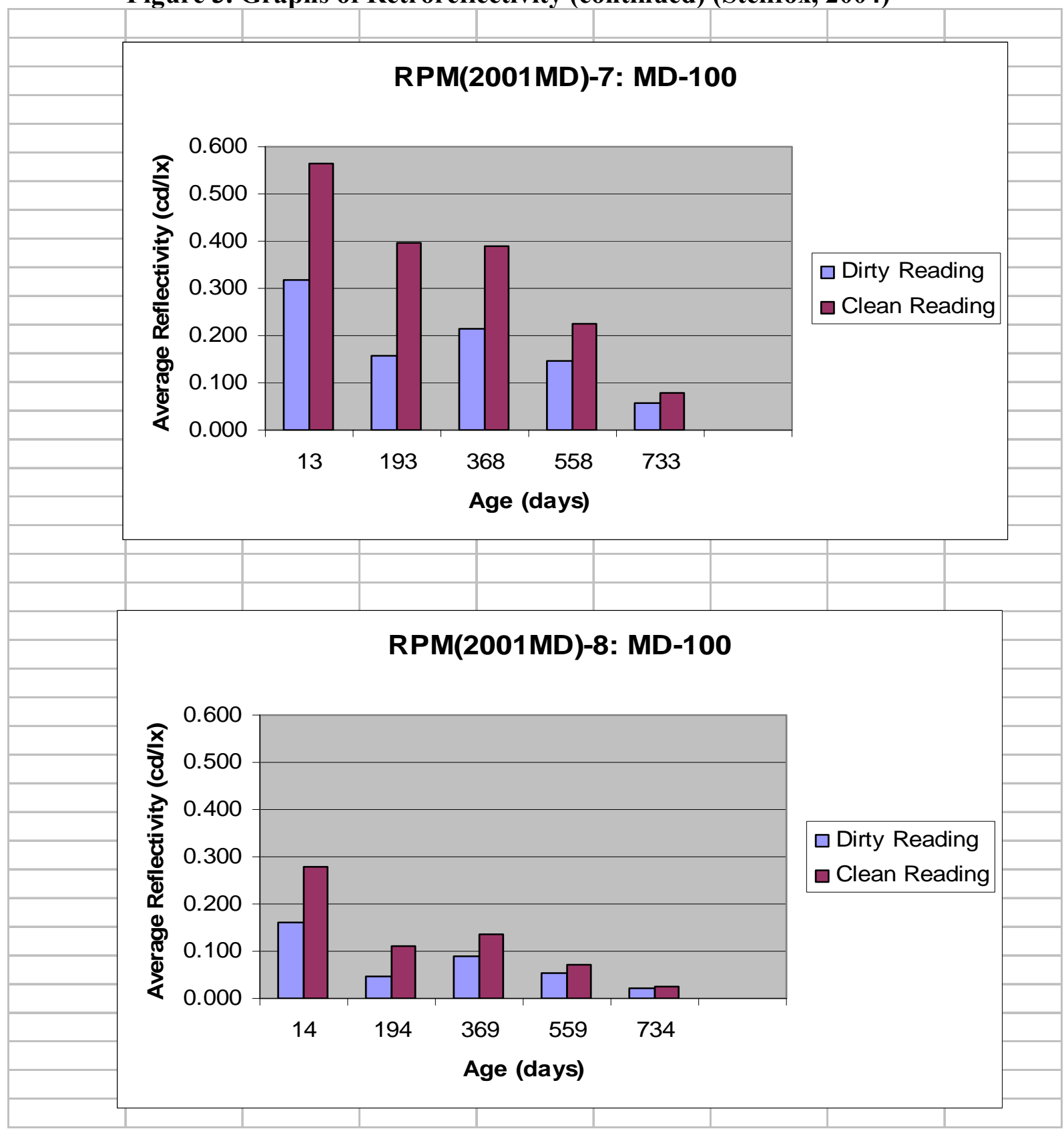


Figure 4. Graphs of Retroreflectivity - I-97 (Stellfox, 2004)
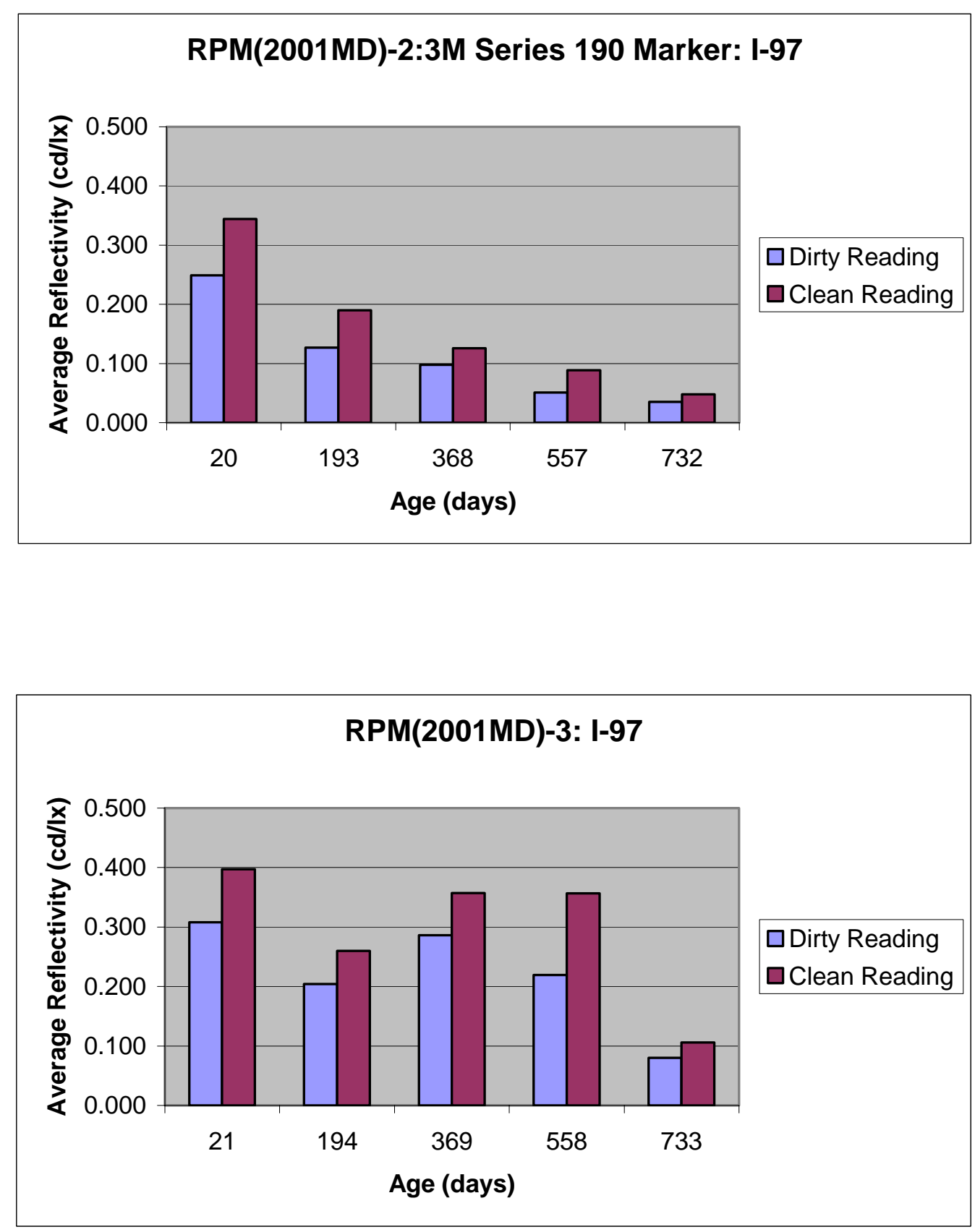
Figure 4. Graphs of Retroreflectivity - I-97 (continued) (Stellfox, 2004)
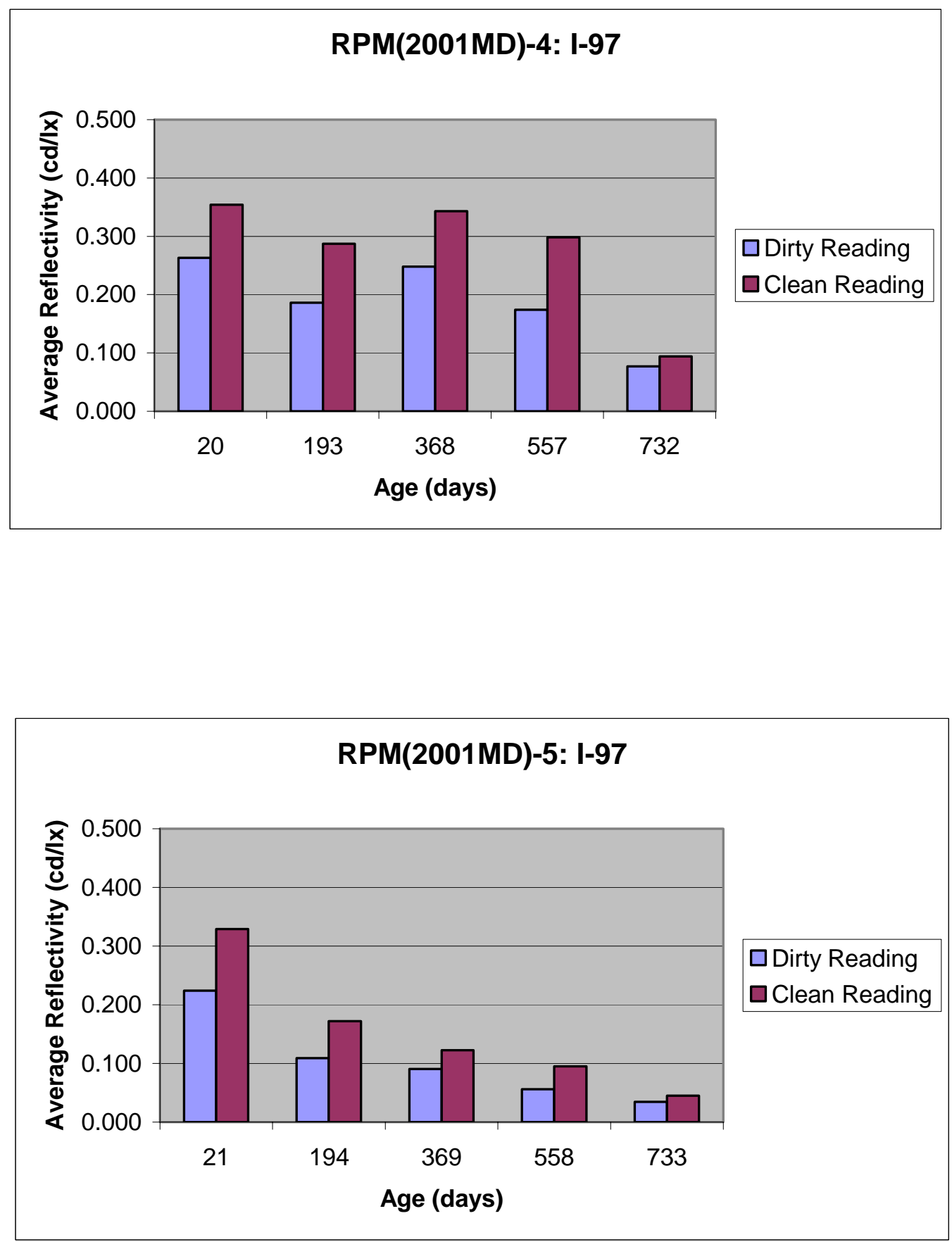
Figure 4. Graphs of Retroreflectivity - I-97 (continued) (Stellfox, 2004)
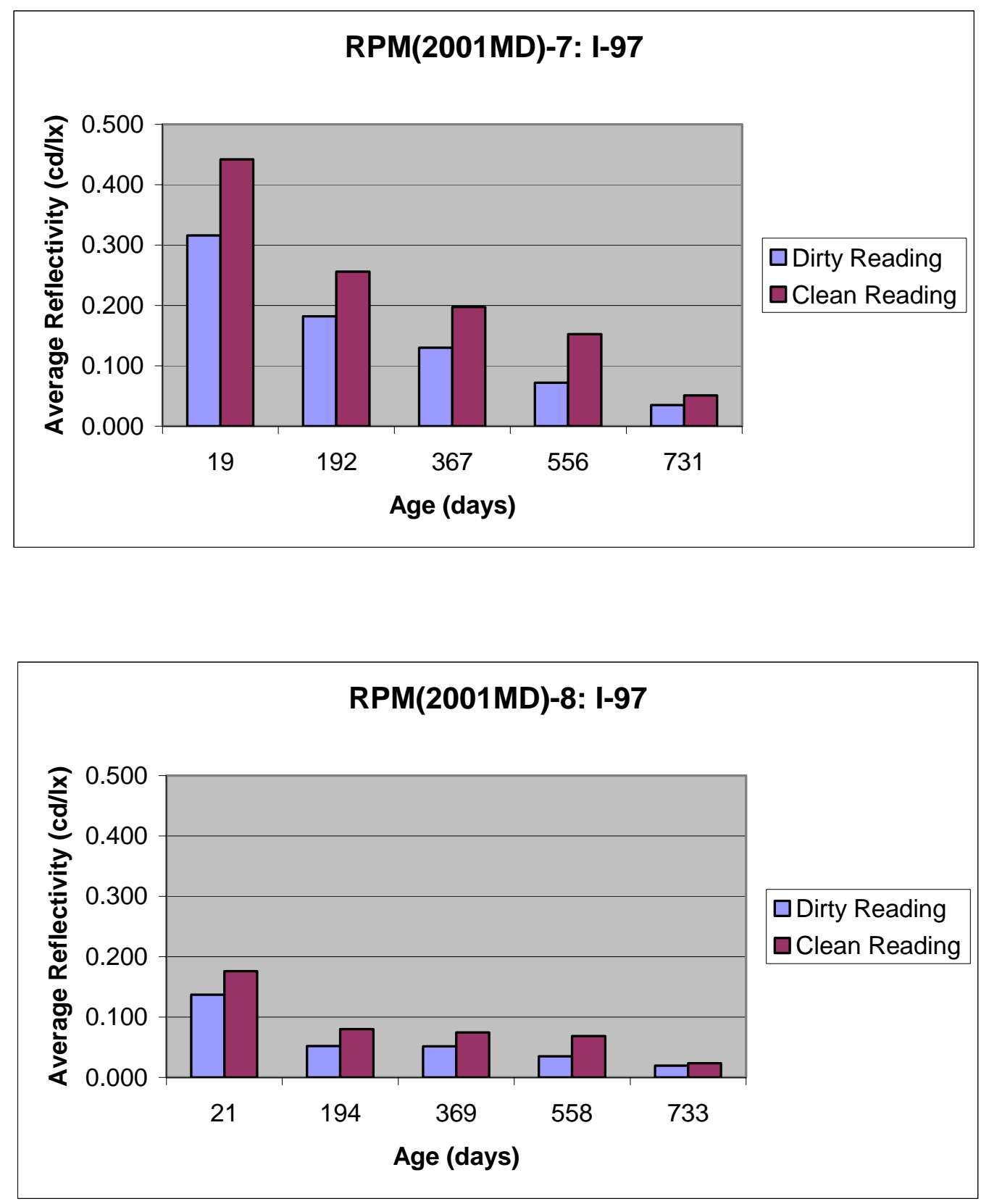
Many researchers have studied the effects of raised pavement markers on highway safety. A Georgia study (Wright et al. 1982) found positive impact of raised pavement marker on safety with $22 \%$ reduction in nighttime crashes. Single-vehicle crashes reduced $12 \%$ more than other nighttime crashes; reduction independent of ADT or horizontal curvature for curves with degree of curvature greater than 6 . A Texas study (Kugle et al. 1984) observed negative impact of raised pavement markers on safety with $15 \%$ to $30 \%$ increase in nighttime crashes; no significant effect on wet weather crashes. Another Texas study (Mak et al. 1987) yielded mixed results $-4.6 \%$ of locations showed significant reductions in nighttime crashes, $10.3 \%$ showed significant increases, $85.1 \%$ showed non-significant effects. The third Texas study (Griffin, 1990) resulted in negative impact on safety $-16.8 \%$ increase in nighttime crashes, with the $95 \%$ confidence interval between a $6.4 \%$ and $28.3 \%$ increase. New York DOT (NYDOT, 1989, and NYDOT, 1997) reported 26\% decrease in nighttime crashes when raised pavement markers were placed selectively, no significant effect when installed non-selectively. A Pennsylvania study (OrthRodgers and Associates, 1998) found significant negative safety impact - 18.1\% overall increase in nighttime crashes, $30 \%$ to $47 \%$ increase in nighttime wet condition crashes, and $56.2 \%$ increase in nighttime wet road sideswipe or fixed-object crashes. The major findings of the above discussed studies are presented in Table 3, including site type, raised pavement marker location, and the safety effects. 
Table 3. Summary of literature on the safety effectiveness of RPMs

\begin{tabular}{|c|c|c|c|}
\hline \multicolumn{4}{|c|}{$\begin{array}{l}\text { Wright, P.H., Zador, P. L., Park, C. Y., \& Karpf, R. S. (1982). Effect of pavement } \\
\text { markers on nighttime crashes in Georgia. Washington, DC, Insurance Institute for } \\
\text { Highway Safety. }\end{array}$} \\
\hline Location & Site Type & $\begin{array}{c}\text { Installation } \\
\text { Location }\end{array}$ & Estimated Effects \\
\hline Georgia & $\begin{array}{l}\text { Horizontal curves } \\
\text { on two-lane } \\
\text { highways in excess } \\
\text { of } 6 \text { degrees of } \\
\text { curvature }\end{array}$ & Centerline & $\begin{array}{l}22 \% \text { reduction in } \\
\text { nighttime crashes; } \\
\text { single-vehicle } \\
\text { crashes reduced } \\
12 \% \text { more than } \\
\text { other nighttime } \\
\text { crashes; reduction } \\
\text { independent of ADT } \\
\text { or horizontal } \\
\text { curvature for curves } \\
\text { with degree of } \\
\text { curvature greater } \\
\text { than } 6 .\end{array}$ \\
\hline \multicolumn{4}{|c|}{$\begin{array}{l}\text { Kugle, C. L., Pendleton, O. J., \& Von Tress, M. S. (1984). An evaluation of the accident } \\
\text { reduction effectiveness of raised pavement markers. College Station, Texas. }\end{array}$} \\
\hline Location & Site Type & $\begin{array}{l}\text { Installation } \\
\text { Location }\end{array}$ & Estimated Effects \\
\hline Texas & $\begin{array}{l}\text { Two-, three-, four-, } \\
\text { five-, and six-lane } \\
\text { roadways }\end{array}$ & Does not specify & $\begin{array}{l}15 \% \text { to } 30 \% \\
\text { increase in } \\
\text { nighttime crashes; } \\
\text { no significant effect } \\
\text { on wet weather } \\
\text { crashes. }\end{array}$ \\
\hline \multicolumn{4}{|c|}{$\begin{array}{l}\text { Mak, K. K., Chira-Chavala, T., \& Griffin, L. I. (1987). Evaluation of the safety effects of } \\
\text { raised pavement markers. College Station, Texas, Texas Transportation Institute. }\end{array}$} \\
\hline Location & Site Type & $\begin{array}{l}\text { Installation } \\
\text { Location }\end{array}$ & Estimated Effects \\
\hline Texas & $\begin{array}{l}\text { Two-, three-, four-, } \\
\text { five-, and six-lane } \\
\text { roadways }\end{array}$ & Does not specify & $\begin{array}{l}4.6 \% \text { of locations } \\
\text { showed significant } \\
\text { reductions in } \\
\text { nighttime crashes, } \\
10.3 \% \text { showed } \\
\text { significant } \\
\text { increases, } 85.1 \% \\
\text { showed non- } \\
\text { significant effects. }\end{array}$ \\
\hline
\end{tabular}


Table 3. Summary of literature on the safety effectiveness of RPMs (continued) Griffin, L. I. (1990). Using the before-and-after design with Yoked comparisons to estimate the effectiveness of accident countermeasures implemented at multiple treatment locations. College Station, Texas, Texas Transportation Institute.

\begin{tabular}{||l|l|l|l|}
\hline \multicolumn{1}{|c|}{ Location } & \multicolumn{1}{|c|}{ Site Type } & Installation Location & \multicolumn{1}{|c|}{ Estimated Effects } \\
\hline Texas & Two-, three-, four-, & Does not specify & $16.8 \%$ increase in \\
& five-, and six-lane & & nighttime crashes, \\
& roadways & & with the $95 \%$ \\
& & & confidence interval \\
& & & \\
& & & \\
& & & \\
& & & \\
\hline
\end{tabular}

Pendleton, O. J. (1996). Evaluation of accident methodology. Station, Texas, Texas Transportation Institute.

\begin{tabular}{|l|l|l|l|}
\hline \multicolumn{1}{|c|}{ Location } & \multicolumn{1}{c|}{ Site Type } & Installation Location & \multicolumn{1}{c|}{ Estimated Effects } \\
\hline Michigan & $\begin{array}{l}\text { Divided and } \\
\text { undivided arterials }\end{array}$ & $\begin{array}{l}\text { Centerline on } \\
\text { undivided arterials, } \\
\text { lane lines on divided } \\
\text { arterials }\end{array}$ & $\begin{array}{l}\text { No significant effect, } \\
\text { direction of effect } \\
\text { positive or negative } \\
\text { dependent on method } \\
\text { used and access } \\
\text { control. }\end{array}$ \\
\hline \hline
\end{tabular}

New York State Department of Transportation (NYDOT). (1989). Highway safety improvement program - annual evaluation report. Albany, NY.

New York State Department of Transportation (NYDOT). (1997). Raised reflectorized snowplowable pavement markers: a report to the Governor. Albany, NY

\begin{tabular}{||l|l|l|l|}
\hline \multicolumn{1}{|c|}{ Location } & \multicolumn{1}{|c|}{ Site Type } & Installation Location & \multicolumn{1}{|c|}{ Estimated Effects } \\
\hline New York & Suburban and rural & Does not specify & 26\% decrease in \\
& roadways & & nighttime crashes \\
& & & when placed \\
& & & selectively, no \\
& & & significant effect \\
when installed non- & selectively. \\
\hline \hline
\end{tabular}

Orth-Rodgers and Associates, Inc. (1998). Safety and congestion management research and advanced technology applications - Final report (technical assistance to the RPM task force). Research Work Order Number 1. Philadelphia, PA.

\begin{tabular}{|l|l|l|l||}
\hline \multicolumn{1}{|c|}{ Location } & \multicolumn{1}{|c|}{ Site Type } & Installation Location & \multicolumn{1}{|c|}{ Estimated Effects } \\
\hline Pennsylvania & $\begin{array}{l}\text { Interstate highways in } \\
\text { rural non-illuminated } \\
\text { areas }\end{array}$ & Does not specify & $\begin{array}{l}18.1 \% \text { overall } \\
\text { increase in nighttime } \\
\text { crashes, nighttime wet } \\
\text { condition crashes } \\
\text { increased from } 30 \% \text { to } \\
47 \%, \text { nighttime wet } \\
\text { road sideswipe or } \\
\text { fixed-object crashes } \\
\end{array}$ \\
& & & increased by $56.2 \%$. \\
\hline
\end{tabular}


With so many studies with conflicting conclusions, it would be hard for one to decide whether raised pavement markers really benefit the motorists with improved highway safety. Fortunately, a comprehensive study sponsored by the National Cooperative Highway Research Program (NCHRP) was conducted to evaluate the safety effects of raised pavement markers. The study results were presented in the NCHRP Report 518 (Bahar et al., 2004) and in Presaud et al. (2004).

The NCHRP study investigated the state of practice for using raised pavement markers. Through survey, the researchers of the NCHRP study obtained information from several states on placement criteria and replacement cycles. The information from these states, including Indiana, is shown in Tables 4 to 7 . These tables show that there are major differences among the states in placement criteria and replacement cycles of raised pavement markers.

The NCHRP study selected six states for the safety evaluation of raised pavement markers as shown in Table 8 . The study collected highway safety data from the six states and analyzed the impacts of raised pavement markers on the safety of two-lane and fourlane roadways. The analyses focused on the effects of raised pavement markers in relation with traffic volume and the degrees of curvatures of horizontal curves. 
Table 4. RPM guidelines based on traffic volume for different roadway types (Bahar et al., 2004)

\begin{tabular}{|c|c|c||}
\hline State & $\begin{array}{c}\text { Guideline for rural } \\
\text { two-lane roadways }\end{array}$ & $\begin{array}{c}\text { Guidelines for multilane } \\
\text { roadways }\end{array}$ \\
\hline Illinois & $\mathrm{ADT}>2,500 \mathrm{veh} /$ day & $\mathrm{ADT}>10,000 \mathrm{veh} /$ day \\
\hline Indiana & $\mathrm{ADT}>2,500 \mathrm{veh} /$ day & $\mathrm{ADT}>6,000 \mathrm{veh} /$ day \\
\hline Kansas & $\mathrm{ADT}>3,000 \mathrm{veh} /$ day and $\mathrm{TADT}>450 \mathrm{veh} /$ day \\
\hline $\mathrm{ADT}=$ average daily traffic (both directions) \\
TADT $=$ truck average daily traffic.
\end{tabular}

Table 5. RPM replacement cycles for the state of Indiana (Bahar et al., 2004)

\begin{tabular}{|c|c|c|}
\hline Number of lanes & ADT (veh/day) & Replacement cycle (years) \\
\hline \multirow{3}{*}{ Two } & Fewer than 5,000 & 4 \\
\cline { 2 - 3 } & 5,000 to 15,000 & 3 \\
\cline { 2 - 3 } & More than 15,000 & 2 \\
\hline \multirow{3}{*}{ Four or more } & Fewer than 10,000 & 4 \\
\cline { 2 - 3 } & 10,000 to 30,000 & 3 \\
\cline { 2 - 3 } & 30,000 to 75,000 & 2 \\
\cline { 2 - 3 } & More than 75,000* & 2 \\
\hline$*$ These roadways should be inspected at least once each year \\
\hline
\end{tabular}

Table 6. When to schedule RPM system maintenance for the state of Texas (based on nighttime inspection) (Bahar et al., 2004)

\begin{tabular}{|c|c|}
\hline \hline For markers spaced at ... & $\begin{array}{c}\text { Maintenance should be scheduled as soon } \\
\text { as possible if ... }\end{array}$ \\
\hline $80 \mathrm{ft}(24 \mathrm{~m})$ & Fewer than two markers are visible \\
\hline $40 \mathrm{ft}(12 \mathrm{~m})$ & Three or fewer markers are visible \\
\hline
\end{tabular}

Table 7. Suggested replacement cycles for RPMs for the state of Texas (Bahar et al., 2004)

\begin{tabular}{|c|c|}
\hline ADT (veh/day) & Replacement cycle (years) \\
\hline More than 50,000 & 1 \\
\hline More than or equal to 10,000 & $2-3$ \\
\hline Fewer than 10,000 & $3-4$ \\
\hline
\end{tabular}


Table 8. States selected for the RPM safety Evaluation (Bahar et al., 2004)

\begin{tabular}{|c|c|c|c|}
\hline State & Roadway Types & $\begin{array}{c}\text { RPM } \\
\text { Implementation } \\
\text { Dates }\end{array}$ & Policy \\
\hline Illinois (District 8) & Two-lane & $1994-1999$ & Nonselective \\
\hline New Jersey & Two-lane & 1993 & Nonselective \\
\hline New York & Two-lane & 1998 & Selective \\
\cline { 2 - 4 } & Four-lane freeway & 1998 & Nonselective \\
\hline Missouri & Four-lane freeway & $1992-2000$ & Nonselective \\
\hline \multirow{2}{*}{$\begin{array}{c}\text { Pennsylvania (Districts } \\
\text { 1, 3, 5, and 8) }\end{array}$} & Two-lane & $1992-2000$ & Selective \\
\cline { 2 - 4 } & Four-lane freeway & $1992-2000$ & Nonselective \\
\cline { 2 - 4 } & Four-lane expressway & $1992-2000$ & Nonselective \\
\hline \multirow{2}{*}{ Wisconsin } & Four-lane freeway & 1999 & Nonselective \\
\cline { 2 - 4 } & Four-lane expressway & 1999 & Nonselective \\
\hline
\end{tabular}

The NCHRP Report 518 (Bahar et al., 2004) provides much needed comprehensive conclusions on the positive and negative impacts of raised pavement markers on highway safety in terms of roadway's geometrical characteristics and traffic conditions. The major findings of the NCHRP study are listed as follows.

1. Expected RPM Impacts on Two-Lane Roadways:

- Decreases in nighttime head-on crashes, with increasing benefits as traffic volumes increase: 1). Improved delineation of the centerline by RPMs at night and the consequent movement away from the centerline will reduce head-on crashes at night. 2). The benefit of RPMs will increase as traffic volumes increase.

- Decreases in safety benefits as the degree of curvature increases: The RPMs will have negative safety effects on roadways with a degree of curvature exceeding 3.5. 
- Decreases in safety benefits as the vehicle moves closer to the edgeline: the risk of run-off-road crashes on two-lane roadways is expected to be higher on roadways with lower design standards (e.g., with higher degrees of curvature and narrower pavement widths) because vehicles move away from the centerline to the edgeline to avoid the RPMs. Narrow shoulder widths reduce the recovery area for vehicles that leave the travel lane. There is a positive correlation between traffic volumes and pavement width, meaning that higher-traffic-volume roadways are normally associated with higher roadway design standards.

- Decreases in wet weather nighttime crashes: the significant improvement in visibility in wet weather at night would be expected to reduce run-off-road crashes and head-on crashes on gentle curves where small increases in speed would not significantly increase crash risk.

- Slight decreases in daytime wet weather crashes: Snowplowable RPMs may improve daytime visibility under wet weather conditions because of the profile of the RPM housing above the film of water covering the painted markings. This improvement in visibility might contribute to a decrease in daytime wet weather crashes.

- Less positive effects of RPMs for gentle curves and less negative effects for sharp curves on roads with illumination when compared with roads without illumination.

2. Expected RPM Impacts on Four-Lane Freeways:

- Decreases in nighttime crashes, with increased benefits at higher traffic volumes: RPMs may only be effective in reducing nighttime crashes on four-lane freeways with AADTs exceeding 20,000 vehicles per day. 
- Decreases in guidance-related crashes (crashes resulting from a vehicle leaving its assigned travelway, such as run-off-road, head-on, encroachment, and sideswipe).

- Decreases in wet weather crashes.

In addition to the above findings, the NCHRP study also established criteria for selecting appropriate roadway sections for use of raised pavement markers. An index, named accident modification factor (AMF), was defined in the report (Bahar et al., 2004) as the ratio between the number of crashes per unit time expected after a measure is implemented and the number of crashes per unit of time estimated if the implementation does not take place. An AMF is mathematically expressed as:

$$
A M F=\frac{\text { expcted number of crashes with } R P M}{\text { expected number of crashes without } R P M}
$$

If $\mathrm{AMF}<1.0$, it means that the raised pavement markers have positive safety effect on the roadway safety. If $\mathrm{AMF}>1.0$, it means that the raised pavement markers have negative safety effect on the roadway safety. Based on the AMF values and safety data from the selected states, the NCHRP study developed criteria for selection of roadways to use raised pavement markers. The criteria are presented in Table 9 and Table 10 for twolane roadways and for four-lane freeways, respectively. As can be seen from Table 9, the effects of raised pavement markers on two-lane roadway safety are affected by traffic volume and horizontal curves. However, Table 10 shows that the effects of raised pavement markers on four-lane freeway are affected only by traffic volume. This is because four-lane freeways do not allow for sharp horizontal curves due to their high design standard. 
Table 9. AMFs for two-lane roadways (nighttime crashes) (Bahar et al., 2004)

\begin{tabular}{|c|c|c||}
\hline $\begin{array}{c}\text { AADT (veh/day) } \\
\text { (Two Directions) }\end{array}$ & $\begin{array}{c}\text { AMF when degree of } \\
\text { curvature } \leq \mathbf{3 . 5}\end{array}$ & $\begin{array}{c}\text { AMF when degree of } \\
\text { curvature }>\mathbf{3 . 5}\end{array}$ \\
\hline $0-5000$ & 1.16 & 1.43 \\
\hline $5001-15000$ & 0.99 & 1.26 \\
\hline $15001--20000$ & 0.76 & 1.03 \\
\hline
\end{tabular}

Table 10. AMFs for four-lane freeways (nighttime crashes) (Bahar et al., 2004)

\begin{tabular}{|c|c||}
\hline \hline $\begin{array}{c}\text { AADT (veh/day) } \\
\text { (Two Directions) }\end{array}$ & AMF \\
\hline$\leq 20000$ & 1.13 \\
\hline $20001-60000$ & 0.94 \\
\hline$>60000$ & 0.67 \\
\hline
\end{tabular}




\section{CHAPTER 3. THE STATE OF PRACTICE OF RAISED PAVEMENT MARKER APPLICATIONS IN INDIANA}

INDOT's guidelines for installing and maintaining raised pavement markers are specified in its design manual, Section 76-3.02(05). The placement considerations are listed in the INDOT Operations Support Memorandum 96-02 and the replacement cycles are shown in the INDOT Operations Support Memorandum 96-03. The two memorandums are included in Appendices $\mathrm{A}$ and $\mathrm{B}$ of this report. The INDOT guidelines indicate that raised pavement markers should be installed in areas of frequent inclement weather (fog, smoke, rain, etc.) and in areas of low roadway illumination. Typical areas that should be considered also include areas where vehicles are leaving the roadway, areas showing excessive wear of existing pavement marking, areas with excessive skid marks, interchange ramps, etc. The guidelines recommend that new raised pavement markers should not installed at locations that are scheduled for resurfacing or reconstruction within four years. Raised pavement markers are not be recommended at illuminated roadway locations. The recommended minimum traffic volumes for placement of raised pavement markers are 2500 ADT for two-lane roadways and 6000 ADT for four-lane roadways. The spacing for raised pavement markers is 24 meters ( 80 feet) on tangent sections and is 12 meters (40 feet) in no-passing zones. The INDOT guidelines for maintenance of raised pavement markers (Memorandum 96-03) suggest replacement cycles of marker lenses be determined based on the number of lanes and traffic volumes. The recommended replacement cycles range from two to four years. 
As can be seen from the Memorandums, the INDOT guidelines are general recommendations. It allows engineers to apply judgment in practice. In order to find out the state of practice of the INDOT districts, a questionnaire survey was sent to the six INDOT districts and the Toll Road Division. The Toll Road Division and all of the six districts responded to the questionnaire survey. The results of the questionnaire survey are summarized in Table 11 through Table 17. The information from the questionnaire survey indicates that the practices of the districts and the Toll Road Division are generally in consistence with the INDOT guidelines for installation and replacement of raised pavement markers. There are some minor differences in the criteria of selecting placement sites. The price for each installed raised pavement marker ranges from $\$ 13$ to \$20. Each lens replacement costs about $\$ 3.3$ to $\$ 8$. In all districts, the spacing between raised pavement markers is 40 feet in no-passing areas and 80 feet in other areas. The roadways of the Toll Road Division are all freeway types and the marker spacing is 100 feet.

The survey results show that the potential negative impact of raised pavement markers on highway safety is not recognized or reflected in INDOT's selection criteria. As discussed early, many previous research projects, especially the NCHRP study, have demonstrated that raised pavement markers may increase vehicle crashes at some roadway locations. Therefore, it is necessary to take advantage of the available research results and to avoid using raised pavement markers on roadway section with potential negative safety effects. 
Table 11. Questionnaire Survey Results - Greenfield District

\begin{tabular}{|c|c|c|c|}
\hline \multirow{18}{*}{ Placement } & \multirow{6}{*}{$\begin{array}{l}\text { Two-Lane } \\
\text { Roadway }\end{array}$} & Selective & Yes \\
\hline & & Non-selective & \\
\hline & & Location & $\begin{array}{l}\text { Centerline, Lane, } \\
\text { Transition }\end{array}$ \\
\hline & & Cost of Each RPM & \\
\hline & & Selection Criteria & ADT and accident histroy \\
\hline & & RPM Spacing & $\begin{array}{c}80 \text { feet on tangent } \\
\text { sections, } 40 \text { feet in no } \\
\text { passing zones }\end{array}$ \\
\hline & \multirow{6}{*}{$\begin{array}{l}\text { Four-Lane } \\
\text { Roadway }\end{array}$} & Selective & Yes \\
\hline & & Non-selective & \\
\hline & & Location & $\begin{array}{l}\text { Centerline, Gore, Lane } \\
\text { Transition }\end{array}$ \\
\hline & & Cost of Each RPM & \\
\hline & & Selection Criteria & ADT and accident histroy \\
\hline & & RPM Spacing & 80 feet \\
\hline & \multirow{6}{*}{$\begin{array}{l}\text { Six-Lane and } \\
\text { Eight-Lane } \\
\text { Roadway }\end{array}$} & Selective & Yes \\
\hline & & Non-selective & \\
\hline & & Location & $\begin{array}{l}\text { Centerline, Gore, Lane } \\
\text { Transition }\end{array}$ \\
\hline & & Cost of Each RPM & \\
\hline & & Selection Criteria & ADT \\
\hline & & RPM Spacing & 80 feet \\
\hline \multirow{6}{*}{ Replacement } & \multirow{3}{*}{$\begin{array}{l}\text { Two-Lane } \\
\text { Roadway }\end{array}$} & Cycle (years) & $\begin{array}{c}\text { ADT }<5000,4 \text { years; } \\
5000<\text { ADT }<15000,3 \text { years; } \\
\text { ADT }>15000,2 \text { years }\end{array}$ \\
\hline & & Criteria & $\begin{array}{l}\text { Age and/or night } \\
\text { inspection }\end{array}$ \\
\hline & & Replacing Parts & Lenses only \\
\hline & \multirow{3}{*}{$\begin{array}{l}\text { Roadway with } \\
\text { Four or More } \\
\text { Lanes }\end{array}$} & Cycle (years) & $\begin{array}{c}\text { ADT }<10000,4 \text { years; } \\
10000<\text { ADT }<30000,3 \\
\text { years; ADT }>30000,2 \\
\text { years }\end{array}$ \\
\hline & & Criteria & $\begin{array}{l}\text { Age and/or night } \\
\text { inspection }\end{array}$ \\
\hline & & Replacing Parts & Lenses only \\
\hline \multicolumn{3}{|c|}{$\begin{array}{l}\text { Follow the INDOT Operations Support Memo } \\
\# 96-02 \text { and } \# 96-03 \text { ? }\end{array}$} & $\begin{array}{l}\text { We follow the guidelines } \\
\text { as the budget allows }\end{array}$ \\
\hline
\end{tabular}


Table 12. Questionnaire Survey Results - Seymour District

\begin{tabular}{|c|c|c|c|}
\hline \multirow{18}{*}{ Placement } & \multirow{6}{*}{$\begin{array}{l}\text { Two-Lane } \\
\text { Roadway }\end{array}$} & Selective & \multirow[t]{2}{*}{ Yes } \\
\hline & & \multirow{2}{*}{$\begin{array}{l}\text { Non-selective } \\
\text { Location }\end{array}$} & \\
\hline & & & $\begin{array}{c}\text { Centerline, Lane lines, } \\
\text { Gore areas }\end{array}$ \\
\hline & & Cost of Each RPM & $\begin{array}{l}\$ 20 \text { for casting and lens } \\
\text { or } \$ 8 \text { for lens only }\end{array}$ \\
\hline & & Selection Criteria & ADT and accident histroy \\
\hline & & RPM Spacing & $\begin{array}{c}80 \text { feet in passing } \\
\text { zones, } 40 \text { feet in no } \\
\text { passing zones }\end{array}$ \\
\hline & \multirow{6}{*}{$\begin{array}{l}\text { Four-Lane } \\
\text { Roadway }\end{array}$} & Selective & \multirow[t]{2}{*}{ Yes } \\
\hline & & Non-selective & \\
\hline & & Location & $\begin{array}{l}\text { Lane lines and } \\
\text { centerlines }\end{array}$ \\
\hline & & Cost of Each RPM & \multirow{2}{*}{$\begin{array}{l}\$ 20 \text { for casting and lens } \\
\text { or } \$ 8 \text { for lens only } \\
\text { ADT and accident histroy }\end{array}$} \\
\hline & & Selection Criteria & \\
\hline & & RPM Spacing & 80 feet \\
\hline & \multirow{6}{*}{$\begin{array}{l}\text { Six-Lane and } \\
\text { Eight-Lane } \\
\text { Roadway }\end{array}$} & Selective & Yes \\
\hline & & Non-selective & \\
\hline & & Location & $\begin{array}{l}\text { Lane lines and } \\
\text { centerlines }\end{array}$ \\
\hline & & Cost of Each RPM & $\begin{array}{l}\$ 20 \text { for casting and lens } \\
\text { or } \$ 8 \text { for lens only }\end{array}$ \\
\hline & & Selection Criteria & ADT and accident histroy \\
\hline & & RPM Spacing & 80 feet \\
\hline \multirow{6}{*}{ Replacement } & \multirow{3}{*}{$\begin{array}{l}\text { Two-Lane } \\
\text { Roadway }\end{array}$} & Cycle (years) & Usually 4 years \\
\hline & & Criteria & $\begin{array}{c}\text { Loss of reflectivity and } \\
\text { excessive missing } \\
\text { castings }\end{array}$ \\
\hline & & Replacing Parts & $\begin{array}{l}\text { District replaces only } \\
\text { lenses. Special clause } \\
\text { in the contract to } \\
\text { replace missing or } \\
\text { broken castings. }\end{array}$ \\
\hline & \multirow{3}{*}{$\begin{array}{l}\text { Roadway with } \\
\text { Four or More } \\
\text { Lanes }\end{array}$} & Cycle (years) & Usually 2 years \\
\hline & & Criteria & $\begin{array}{c}\text { Loss of reflectivity and } \\
\text { excessive missing } \\
\text { castings }\end{array}$ \\
\hline & & Replacing Parts & $\begin{array}{l}\text { District replaces only } \\
\text { lenses. Special clause } \\
\text { in the contract to }\end{array}$ \\
\hline
\end{tabular}




\begin{tabular}{|l|l|c|}
\hline & & $\begin{array}{l}\text { replace missing or } \\
\text { broken castings. }\end{array}$ \\
\hline $\begin{array}{l}\text { Follow the INDOT Operations Support Memo } \\
\text { \#96-02 and \#96-03? }\end{array}$ & We try to follow the \\
Memo.
\end{tabular}


Table 13. Questionnaire Survey Results - Vincennes District

\begin{tabular}{|c|c|c|c|}
\hline & & Selective & \\
\hline & & Non-selective & Yes \\
\hline & Two-Lane & Location & $\begin{array}{l}\text { Centerlines and Turn Lane } \\
\text { Lines. Not installed in } \\
\text { areas with existing street } \\
\text { lighting. }\end{array}$ \\
\hline & Roadway & Cost of Each RPM & $\begin{array}{l}\text { Last contract: } \$ 18.67 \text { each } \\
\text { RPM and } \$ 3.30 \text { for lens } \\
\text { replacement. }\end{array}$ \\
\hline & & Selection Criteria & \\
\hline & & RPM Spacing & $\begin{array}{l}80 \text { feet on centerlines with } \\
40 \text { feet on the turn lane } \\
\text { lines }\end{array}$ \\
\hline & & Selective & \\
\hline & & Non-selective & Yes \\
\hline & & Location & $\begin{array}{c}\text { Centerlines and Turn Lane } \\
\text { Lines. Not installed in } \\
\text { areas with existing street } \\
\text { lighting. }\end{array}$ \\
\hline Placement & Roadway & Cost of Each RPM & $\begin{array}{l}\text { Last contract: } \$ 18.67 \text { each } \\
\text { RPM and } \$ 3.30 \text { for lens } \\
\text { replacement. }\end{array}$ \\
\hline & & Selection Criteria & \\
\hline & & RPM Spacing & $\begin{array}{c}80 \text { feet on centerlines with } \\
40 \text { feet on the turn lane } \\
\text { lines }\end{array}$ \\
\hline & & Selective & \\
\hline & & Non-selective & Yes \\
\hline & Six-Lane and & Location & $\begin{array}{c}\text { Centerlines and Turn Lane } \\
\text { Lines. Not installed in } \\
\text { areas with existing street } \\
\text { lighting. }\end{array}$ \\
\hline & $\begin{array}{l}\text { Eight-Lane } \\
\text { Roadway }\end{array}$ & Cost of Each RPM & $\begin{array}{l}\text { Last contract: } \$ 18.67 \text { each } \\
\text { RPM and } \$ 3.30 \text { for lens } \\
\text { replacement. }\end{array}$ \\
\hline & & Selection Criteria & \\
\hline & & RPM Spacing & $\begin{array}{l}80 \text { feet on centerlines with } \\
40 \text { feet on the turn lane } \\
\text { lines }\end{array}$ \\
\hline Replacement & & Cycle (years) & $\begin{array}{l}\text { We follow the guidelines in } \\
\text { operation Support Memo } 96-\Theta 3\end{array}$ \\
\hline & Two-Lane & Criteria & \\
\hline & Roadway & Replacing Parts & $\begin{array}{l}\text { Lenses only. Castings are } \\
\text { replaced when they are } \\
\text { damaged or missing. }\end{array}$ \\
\hline & $\begin{array}{l}\text { Roadway with } \\
\text { Four or More }\end{array}$ & Cycle (years) & $\begin{array}{l}\text { We follow the guidelines in } \\
\text { operation Support Memo } 96-03\end{array}$ \\
\hline & & Criteria & \\
\hline
\end{tabular}




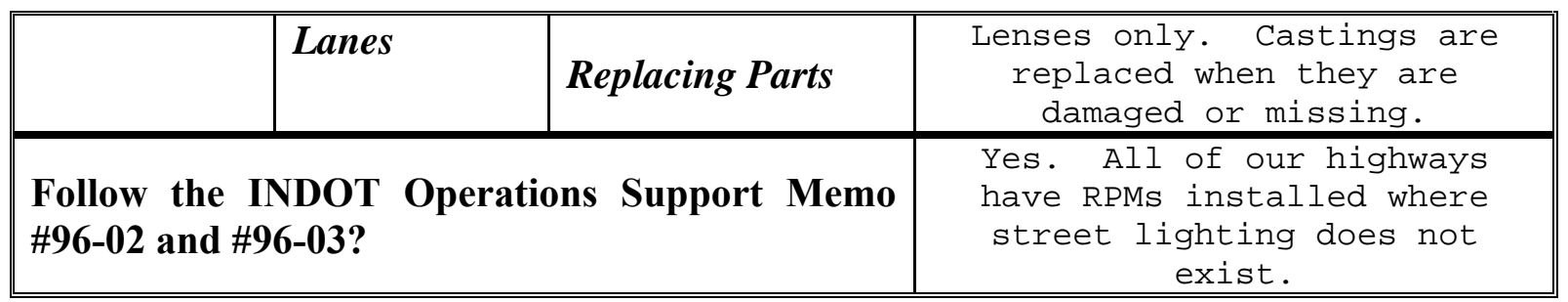


Table 14. Questionnaire Survey Results - Crawfordsville District

\begin{tabular}{|c|c|c|c|}
\hline \multirow{18}{*}{ Placement } & \multirow{6}{*}{$\begin{array}{l}\text { Two-Lane } \\
\text { Roadway }\end{array}$} & Selective & Yes \\
\hline & & Non-selective & \multirow[b]{2}{*}{ Centerline } \\
\hline & & Location & \\
\hline & & Cost of Each RPM & $\begin{array}{c}\$ 3.8 \text { for lens and } \$ 13.00 \\
\text { for new installation. }\end{array}$ \\
\hline & & Selection Criteria & $\begin{array}{l}\text { Where ADT > 1000, not in } \\
\text { low speed lit areas } \\
\text { (cities and towns) }\end{array}$ \\
\hline & & RPM Spacing & $\begin{array}{l}80 \text { feet in apssing } \\
\text { areas, } 40 \text { feet in no } \\
\text { passing zones }\end{array}$ \\
\hline & \multirow{6}{*}{$\begin{array}{l}\text { Four-Lane } \\
\text { Roadway }\end{array}$} & Selective & Yes \\
\hline & & Non-selective & \\
\hline & & Location & Centerline \\
\hline & & Cost of Each RPM & $\begin{array}{c}\$ 3.8 \text { for lens and } \$ 13.00 \\
\text { for new installation. }\end{array}$ \\
\hline & & Selection Criteria & $\begin{array}{l}\text { Where ADT > 1000, not in } \\
\text { low speed lit areas } \\
\text { (cities and towns) }\end{array}$ \\
\hline & & RPM Spacing & $\begin{array}{l}80 \text { feet in apssing } \\
\text { areas, } 40 \text { feet in no } \\
\text { passing zones }\end{array}$ \\
\hline & \multirow{6}{*}{$\begin{array}{l}\text { Six-Lane and } \\
\text { Eight-Lane } \\
\text { Roadway }\end{array}$} & Selective & Yes \\
\hline & & Non-selective & \\
\hline & & Location & Centerline \\
\hline & & Cost of Each RPM & $\begin{array}{c}\$ 3.8 \text { for lens and } \$ 13.00 \\
\text { for new installation. }\end{array}$ \\
\hline & & Selection Criteria & $\begin{array}{c}\text { Where ADT > 1000, not in } \\
\text { low speed lit areas } \\
\text { (cities and towns) }\end{array}$ \\
\hline & & RPM Spacing & $\begin{array}{l}80 \text { feet in apssing } \\
\text { areas, } 40 \text { feet in no } \\
\text { passing zones }\end{array}$ \\
\hline \multirow{6}{*}{ Replacement } & \multirow{3}{*}{$\begin{array}{l}\text { Two-Lane } \\
\text { Roadway }\end{array}$} & Cycle (years) & 4 years \\
\hline & & Criteria & $\begin{array}{l}\text { Nighttime visual } \\
\text { inspection }\end{array}$ \\
\hline & & Replacing Parts & $\begin{array}{l}\text { Lenses only. New } \\
\text { installation on newly } \\
\text { resurfaced roads only. }\end{array}$ \\
\hline & \multirow{3}{*}{$\begin{array}{l}\text { Roadway with } \\
\text { Four or More } \\
\text { Lanes }\end{array}$} & Cycle (years) & $\begin{array}{c}\text { Interstate } 2 \text { year, other } \\
3 \text { years. }\end{array}$ \\
\hline & & Criteria & $\begin{array}{l}\text { Nighttime visual } \\
\text { inspection }\end{array}$ \\
\hline & & Replacing Parts & Lenses only. New \\
\hline
\end{tabular}




\begin{tabular}{|c|c|c|}
\hline & & $\begin{array}{l}\text { installation on newly } \\
\text { resurfaced roads only. }\end{array}$ \\
\hline $\begin{array}{l}\text { Follow the IN } \\
\# 96-02 \text { and } \# 96\end{array}$ & $\begin{array}{l}\text { NDOT Operations Support Memo } \\
\text { 6-03? }\end{array}$ & $\begin{array}{l}\text { Yes, except we go to } \\
\text { lower ADT (ADT>1000). }\end{array}$ \\
\hline
\end{tabular}


Table 15. Questionnaire Survey Results - Fort Wayne District

\begin{tabular}{|c|c|c|c|}
\hline \multirow{18}{*}{ Placement } & \multirow{6}{*}{$\begin{array}{l}\text { Two-Lane } \\
\text { Roadway }\end{array}$} & Selective & Yes, follow Memo 96-02. \\
\hline & & Non-selective & \\
\hline & & Location & $\begin{array}{c}\text { Centerlines, lane lines } \\
\text { and gore areas. }\end{array}$ \\
\hline & & Cost of Each RPM & \\
\hline & & Selection Criteria & \\
\hline & & RPM Spacing & \\
\hline & \multirow{6}{*}{$\begin{array}{l}\text { Four-Lane } \\
\text { Roadway }\end{array}$} & \begin{tabular}{|l} 
Selective \\
\end{tabular} & Yes, follow Memo 96-02. \\
\hline & & \begin{tabular}{|l} 
Non-selective \\
\end{tabular} & \\
\hline & & Location & $\begin{array}{c}\text { Centerlines, lane lines } \\
\text { and gore areas. }\end{array}$ \\
\hline & & Cost of Each RPM & \\
\hline & & Selection Criteria & \\
\hline & & RPM Spacing & \\
\hline & \multirow{6}{*}{$\begin{array}{l}\text { Six-Lane and } \\
\text { Eight-Lane } \\
\text { Roadway }\end{array}$} & Selective & \multirow{6}{*}{$\begin{array}{l}\text { No six or eight lane } \\
\text { highways in this } \\
\text { district. }\end{array}$} \\
\hline & & \begin{tabular}{|l|} 
Non-selective \\
\end{tabular} & \\
\hline & & Location & \\
\hline & & Cost of Each RPM & \\
\hline & & Selection Criteria & \\
\hline & & RPM Spacing & \\
\hline \multirow{6}{*}{ Replacement } & \multirow{3}{*}{$\begin{array}{l}\text { Two-Lane } \\
\text { Roadway }\end{array}$} & Cycle (years) & 4 years \\
\hline & & Criteria & Per Memo 96-02 \\
\hline & & Replacing Parts & Lenses only. \\
\hline & \multirow{3}{*}{$\begin{array}{l}\text { Roadway with } \\
\text { Four or More } \\
\text { Lanes }\end{array}$} & Cycle (years) & 4 years \\
\hline & & Criteria & Per Memo 96-02 \\
\hline & & Replacing Parts & Lenses only. \\
\hline \multicolumn{3}{|c|}{$\begin{array}{l}\text { Follow the INDOT Operations Support Memo } \\
\# 96-02 \text { and } \# 96-03 \text { ? }\end{array}$} & $\begin{array}{c}\text { Yes, to the best of our } \\
\text { abilities. }\end{array}$ \\
\hline
\end{tabular}


Table 16. Questionnaire Survey Results - LaPort District

\begin{tabular}{|c|c|c|c|}
\hline \multirow{18}{*}{ Placement } & \multirow{6}{*}{$\begin{array}{l}\text { Two-Lane } \\
\text { Roadway }\end{array}$} & Selective & Yes \\
\hline & & Non-selective & \\
\hline & & Location & $\begin{array}{c}\text { Centerlines and turn } \\
\text { lines }\end{array}$ \\
\hline & & Cost of Each RPM & \\
\hline & & Selection Criteria & \\
\hline & & RPM Spacing & $\begin{array}{l}\text { Model } 101 \text { Stimsonite } \\
\text { Markers. } 4 \odot \text { feet and } 80 \\
\text { feet on centerlines and } \\
4 \odot \text { feet on turn lanes }\end{array}$ \\
\hline & & Selective & Yes \\
\hline & & Non-selective & \\
\hline & & Location & $\begin{array}{c}\text { Centerlines, lane lines } \\
\text { and gore and island } \\
\text { areas. }\end{array}$ \\
\hline & $\begin{array}{l}\text { Four-Lane } \\
\text { Roadway }\end{array}$ & Cost of Each RPM & \\
\hline & & Selection Criteria & \\
\hline & & RPM Spacing & $\begin{array}{c}\text { Model } 101 \text { Stimsonite } \\
\text { Markers. } 80 \text { feet on lane } \\
\text { lines and } 40 \text { feet in } \\
\text { gore and island areas. }\end{array}$ \\
\hline & & Selective & Yes \\
\hline & & Non-selective & \\
\hline & Six-Lane and & Location & $\begin{array}{c}\text { Centerlines, lane lines } \\
\text { and gore and island } \\
\text { areas. }\end{array}$ \\
\hline & Eight-Lane & Cost of Each RPM & \\
\hline & Roadway & Selection Criteria & \\
\hline & & RPM Spacing & $\begin{array}{l}\text { Model } 101 \text { Stimsonite } \\
\text { Markers. } 80 \text { feet on lane } \\
\text { lines and } 40 \text { feet in } \\
\text { gore and island areas. }\end{array}$ \\
\hline & & Cycle (years) & 3 to 4 years \\
\hline & Two-Lane & Criteria & Per ADT \\
\hline & Roadway & Replacing Parts & $\begin{array}{l}\text { Lens only. Castings if } \\
\text { loose or broken }\end{array}$ \\
\hline Replacement & Roadway with & Cycle (years) & $\begin{array}{c}2 \text { years on interstate } \\
\text { and } 3 \text { to } 4 \text { years on } \\
\text { other }\end{array}$ \\
\hline & Four or More & Criteria & Per ADT \\
\hline & & Replacing Parts & $\begin{array}{l}\text { Lens only. Castings if } \\
\text { loose or broken }\end{array}$ \\
\hline Follow the & DOT Operati & ons Support Memo & Yes \\
\hline
\end{tabular}


\#96-02 and \#96-03? 
Table 17. Questionnaire Survey Results - Toll Road District

\begin{tabular}{|c|c|c|c|}
\hline \multirow{18}{*}{ Placement } & \multirow{6}{*}{$\begin{array}{l}\text { Two-Lane } \\
\text { Roadway }\end{array}$} & Selective & \\
\hline & & Non-selective & \\
\hline & & Location & \\
\hline & & Cost of Each RPM & \\
\hline & & Selection Criteria & \\
\hline & & RPM Spacing & \\
\hline & \multirow{6}{*}{$\begin{array}{l}\text { Four-Lane } \\
\text { Roadway }\end{array}$} & Selective & \\
\hline & & Non-selective & $\begin{array}{c}\text { Yes, } 157 \text { centerline } \\
\text { miles of interstate } \\
\text { class road }\end{array}$ \\
\hline & & Location & $\begin{array}{l}\text { Centerline, and } \\
\text { edgelines at ramps only }\end{array}$ \\
\hline & & Cost of Each RPM & $\begin{array}{l}\text { \$16.37 includes removal } \\
\text { and replacement during } \\
\text { contract paving. } \\
\text { Stimsonite Low Profile- } \\
\text { Oneway Type Model } 96 .\end{array}$ \\
\hline & & Selection Criteria & \\
\hline & & RPM Spacing & 100 feet \\
\hline & \multirow{6}{*}{$\begin{array}{l}\text { Six-Lane and } \\
\text { Eight-Lane } \\
\text { Roadway }\end{array}$} & Selective & \\
\hline & & Non-selective & \\
\hline & & Location & \\
\hline & & Cost of Each RPM & \\
\hline & & Selection Criteria & \\
\hline & & RPM Spacing & \\
\hline \multirow{6}{*}{ Replacement } & \multirow{3}{*}{$\begin{array}{l}\text { Two-Lane } \\
\text { Roadway }\end{array}$} & Cycle (years) & $\begin{array}{l}8 \text { years and at pavement } \\
\text { resurfacing time. }\end{array}$ \\
\hline & & Criteria & \\
\hline & & Replacing Parts & $\begin{array}{l}\text { Replace lens at } 3 \text { to } 4 \\
\text { year interval. }\end{array}$ \\
\hline & \multirow{3}{*}{$\begin{array}{l}\text { Roadway with } \\
\text { Four or More } \\
\text { Lanes }\end{array}$} & Cycle (years) & \\
\hline & & Criteria & \\
\hline & & Replacing Parts & \\
\hline \multicolumn{3}{|c|}{$\begin{array}{l}\text { Follow the INDOT Operations Support Memo } \\
\# 96-02 \text { and } \# 96-03 ?\end{array}$} & $\begin{array}{l}\text { RPMs are placed } 4 \text { inches } \\
\text { to the right of the } \\
\text { geometric center of the } \\
\text { pavement to avoid } \\
\text { placing over the paving } \\
\text { joint. }\end{array}$ \\
\hline
\end{tabular}




\section{CHAPTER 4. CONCLUSIONS AND RECOMMENDATIONS}

As discussed in the previous chapters, the effects of raised pavement markers on roadway safety could be positive or negative, depending on the traffic conditions and geometric characteristics of the roadway. The effectiveness of raised pavement markers has been analyzed in many studies. All of these studies, except for the NCHRP study (Bahar et al., 2004), focused on one or a few roadway sections. Because of the different characteristics of the roadways involved in the studies, they produced different or even conflicting results on the safety effects. The NCHRP study was performed with the vehicle crash data from several states in order to overcome the shortcomings of the individual studies. The NCHRP study conformed that raised pavement markers could have either positive or negative effects on highway safety. Generally, raised pavement markers can improve highway safety when traffic volume is relatively high and the degree of curvature of the horizontal curve is low (i.e., the curve is gentle). The NCHRP study resulted in quantitative guidelines for selecting appropriate roadway sections for placement of raised pavement markers.

The NCHRP Report 518 was published in 2004. The results from the NCHRP study may not have been reviewed or digested by all the State DOTs because of its fairly recent publication. As recommended by the Study Advisory Committee of this synthesis study, several State DOTs were contacted to see if they have adopted or plan to adopt the NCHRP guideline for raised pavement markers. The State DOTs, including Illinois, Iowa, Pennsylvania, and Michigan, have not adopted the NCHRP guidelines. Illinois 
DOT is currently reviewing its policies on raised pavement markers and will include the NCHRP Report 518 in its review. However, Iowa, Pennsylvania, and Michigan indicated that they do not plan to adopt the NCHRP guidelines.

Through this synthesis study, it is believed that the research methods employed in the NCHRP study are theoretically sound, the data used are representative, and the research results are comprehensive and reasonable. It is therefore recommend that the NCHRP study results be applied by INDOT in order to further improve the highway safety in Indiana. The core results of the NCHRP study are the criteria presented in Tables 9 and 10, which appear at the end of Chapter 2 of this report. The two tables are also shown below for reader's convenience.

Table 9. AMFs for two-lane roadways (nighttime crashes) (Bahar et al., 2004)

\begin{tabular}{|c|c|c|}
\hline $\begin{array}{c}\text { AADT (veh/day) } \\
\text { (Two Directions) }\end{array}$ & $\begin{array}{c}\text { AMF when degree of } \\
\text { curvature } \leq \mathbf{3 . 5}\end{array}$ & $\begin{array}{c}\text { AMF when degree of } \\
\text { curvature }>\text { 3.5 }\end{array}$ \\
\hline $0-5000$ & 1.16 & 1.43 \\
\hline $5001-15000$ & 0.99 & 1.26 \\
\hline $15001--20000$ & 0.76 & 1.03 \\
\hline
\end{tabular}

Table 10. AMFs for four-lane freeways (nighttime crashes) (Bahar et al., 2004)

\begin{tabular}{|c|c|}
\hline $\begin{array}{c}\text { AADT (veh/day) } \\
\text { (Two Directions) }\end{array}$ & AMF \\
\hline$\leq 20000$ & 1.13 \\
\hline $20001-60000$ & 0.94 \\
\hline$>60000$ & 0.67 \\
\hline
\end{tabular}

Note: $A M F=\frac{\text { expcted number of crashes with } R P M}{\text { expected number of crashes without } R P M}$ 
The proposed guidelines in the NCHRP Report are based on the criteria in the two tables. The NCHRP guidelines for raised pavement markers on two-lane roadways are as follows (Bahar et al., 2004):

- AMFs shown in Table 9 should be used to guide decisions on where not to install raised pavement markers (i.e., when an AMF is greater than 1). An AMF less than 1 would indicate a positive safety effect (i.e., a reduction in crashes), while an AMF greater than 1 would indicated a negative safety effect (i.e., an increase in crashes).

- Given the negative safety impact that are demonstrated to be associated with curves with more than 3.5 degrees of curvature, and given the findings of speed increases in association with raised pavement markers, it would seem prudent to avoid placing raised pavement markers well in advance of roadway sections with substandard geometry or where the feature is unexpected because of the character of the road previously encountered by the driver.

- An analytical engineering procedure should be undertaken at locations where an AMF is less than 1 to assess the cost-effectiveness of raised pavement marker installation.

- The results of the analytical engineering procedure should form part of the decision-making process for whether to install raised pavement markers at a given location. Other issues to be considered with this information are - Other measures for improving nighttime crashes that may result in higher benefit-cost effectiveness and 
- Other locations that may result in a higher-than-expected cost-effectiveness from the installation of raised pavement markers (thus, the results of the engineering study should be entered into the safety resource allocation process).

The NCHRP guidelines for raised pavement markers on four-lane roadways are as follows (Bahar et al., 2004):

- AMFs shown in the table should be used to guide decisions on where to install raised pavement markers (i.e., when an AMF is less than 1).

- An analytical engineering procedure should be undertaken if a cost-effectiveness study is required.

The NCHRP guidelines should be incorporated into INDOT's policies or guidelines for raised pavement markers. The criteria of the guidelines are based on traffic volumes for four-lane roadways and on traffic volumes and degrees of curvature for two-lane roadways. Both of traffic volume and degree of curvature are readily available for the state managed highways in Indiana, therefore the guidelines can be easily implemented.

It should be noted that the NCHRP guidelines for two-lane roadways did not discuss the "winding" two-lane roadways that are common in some Indiana highways. The "winding" two-lane roadways contain highway sections that have a number of consecutive sharp curves with degrees of curvature often greater than 3.5. Raised pavement markers on these highway sections could probably provide positive safety 
impact. Therefore, for the winding sections of Indiana highways, INDOT engineers should determine the use of raised pavement markers based on traffic conditions, engineering analysis, and professional judgment.

The raised pavement marker spacing, 80 feet on tangent section and 40 feet in nopassing zones, is specified in many states as well as in Indiana. The replacement cycles of raised pavement marker lenses recommended in the INDOT Memorandums seem reasonable and similar to those in other states. As practiced in several INDOT districts and some other states, lens replacement should be determined by age as well as by visual inspection. In Texas, raised pavement markers should be replaced or maintained as soon as possible if nighttime inspection shows that fewer than two markers are visible for 80 feet marker spacing or three or fewer markers are visible for 40 feet marker spacing. Hence, in addition to marker age, it should be helpful if INDOT would also include some types of visual inspection or retroreflectivity measurement in its guidelines for determination of marker or marker lens replacement. 


\section{REFERENCES}

Hammond, J. L., \& Wegmann, F. J. (2001). Daytime effects of raised pavement markers on horizontal curves. ITE Journal, 38-41.

Zwahlen, H. T., \& Schnell, T. (2000). Minimum in-service retroreflectivity of pavement markings. Transportation Research Record 1715, 60-70.

Stellfox, E. (2004). Evaluation of Snowplowable, Retroreflective Raised Pavement Markers. Final Report, MD-04-SP208B4G. The Maryland State Highway Administration.

Wright, P.H., Zador, P. L., Park, C. Y., \& Karpf, R. S. (1982). Effect of pavement markers on nighttime crashes in Georgia. Washington, DC, Insurance Institute for Highway Safety.

Kugle, C. L., Pendleton, O. J., \& Von Tress, M. S. (1984). An evaluation of the accident reduction effectiveness of raised pavement markers. College Station, Texas.

Mak, K. K., Chira-Chavala, T., \& Griffin, L. I. (1987). Evaluation of the safety effects of raised pavement markers. College Station, Texas, Texas Transportation Institute.

Griffin, L. I. (1990). Using the before-and-after design with Yoked comparisons to estimate the effectiveness of accident countermeasures implemented at multiple treatment locations. College Station, Texas, Texas Transportation Institute.

Pendleton, O. J. (1996). Evaluation of accident methodology. Station, Texas, Texas Transportation Institute.

New York State Department of Transportation (NYDOT). (1989). Highway safety improvement program - annual evaluation report. Albany, NY.

New York State Department of Transportation (NYDOT). (1997). Raised reflectorized snowplowable pavement markers: a report to the Governor. Albany, NY.

Orth-Rodgers and Associates, Inc. (1998). Safety and congestion management research and advanced technology applications - Final report (technical assistance to the RPM task force). Research Work Order Number 1. Philadelphia, PA.

Bahar, G., Mollett, C., Presaud, B., Lyon, C., Smiley, A., Smahel, T., \& McGee, H. (2004). Safety evaluation of permanent raised pavement markers. NCHRP Report 518. Transportation Research Board.

Presaud, B., Bahar, G., Mollett, C., \& Lyon, C. (2004). Safety evaluation of permanent raised pavement markers. Transportation Research Record 1897, 148-155. 
Bahar, G., Mollett, C., Presaud, B., Lyon, C., Smiley, A., Smahel, T., \& McGee, H. (2004). Safety evaluation of permanent raised pavement markers. NCHRP Report 518. Transportation Research Board.

Presaud, B., Bahar, G., Mollett, C., \& Lyon, C. (2004). Safety evaluation of permanent raised pavement markers. Transportation Research Record 1897, 148-155. 


\section{Appendix A: Memorandum 96-02 - Snowplowable Raised Pavement Markers Guidelines for Installation at New Location}


INDIANA DEPARTMENT OF TRANSPORTATION

INDIANAPOLIS, INDIANA 46204-2249

INTER-DEPARTMENT COMMUNICATION

April 26, 1996

TRAFFIC MEMORANDUM 96-02 PAVEMENT MARKINGS

MEMORANDUM:

TO:

$\begin{array}{ll}\text { TO: } & \text { District Traffic Engineers } \\ \text { FROM: } & \begin{array}{l}\text { Timothy D. Bertram, } \\ \text { Opherations Support Division }\end{array}\end{array}$

SUBJECT: SNOWPLOWABLE RAISED PAVEMENT MARKERS

GUIDELINES FOR INSTALLATION AT NEW LOCATION

Site selection and criteria for the installation of snowplowable raised pavement markers shall normally be according the "Design Manual - Indiana Department of Transportation" current version of section 76-3.02(05).

The following is the current $(4 / 26 / 96)$ version of the noted section:

76-3.02(05)

RAISED PAVEMENT MARKERS (RPM's)

Snowplowable RPM's provide a supplemental method of delineation and are positive position guidance devices. They should not be used as a replacement for standard pavement markings or conventional roadside delineation. The INDOT Standard Drawings provide details on the

placement and color locations for RPM's. In addition, the following placement considerations should be reviewed.

1. Location. Site selection should be based primarily on the need for additional alignment delineation specifically in areas of frequently inclement weather (e.g., fog, smoke, rain) and in areas of low roadway illumination. Typical areas that should be considered for placement of RPM's include areas where vehicles are leaving the roadway, areas showing excessive wear of existing pavement markings, areas with excessive skid marks, interchange ramps, etc.

2. Pavement Life. RPM's generally should not be placed at locations that are scheduled for resurfacing or reconstruction within the next four years.

3. Illumination. RPM's may not be required at locations that are illuminated. 
MEMORANDUM - PAGE 2 OF 2

Snowplowable RPM's

Installation New Locations

April 26, 1996

4. Traffic Volumes. RPM's should be considered where traffic volumes exceed 2500 ADT for 2-lane roadways and 6000 ADT for 4-lane roadways. On lower volume roads, an engineering investigation should be conducted to determine whether RPM's may be appropriate to supplement the standard traffic control devices.

5. Spacing. The normal spacing for RPM's on tangent sections is $24 \mathrm{~m}$. Spacing for centerline RPM's used in conjunction with no-passing zones may be reduced to $12 \mathrm{~m}$. Six RPM's at $12 \mathrm{~m}$ spacing $(72 \mathrm{~m})$ may be used in advance of and following any delineated no-passing zone. Consideration should be given to connecting two locations or zones of RPM's where the distance between them is less than $900 \mathrm{~m}$. See the INDOT Standard Drawings for additional details for spacing at other locations.

6. Special Locations. Typically, RPM's should not be used exclusively for edge lines or gore markings. RPM's may be allowed at pavement transitions, 1-way and narrow bridges, special channelization areas, or in other areas where there is strong justification for installation of these devices.

TDB:CTT:ctt

cc: Jim Poturalski

Homer Unger

Sami Mohamed

Larry Goode (3)
Mike Lindley

Ed Cox

Frank Vukovits

Traffic Field Engineers (3) 


\section{Appendix B: Memorandum 96-03 - Snowplowable Raised Pavement Markers Maintenance}




\section{INDIANA DEPARTMENT OF TRANSPORTATION}

INDIANAPOLIS, INDIANA 46204.2249

INTER-DEPARTMENT COMMUNICATION

April 26, 1996

TRAFFIC MEMORANDUM 96-03

MEMORANDUM:

TO:

FROM:

District Traffic Engineers

Timothy D. Bertram, Chief

Operations Support Division

\section{SUBJECT: SNOWPLOWABLE RAISED PAVEMENT MARKERS (RPM)} MAINTENANCE

The district traffic section will be the lead for the maintenance and refurbishment of reflectorized snowplowable raised pavement markers.

It is necessary to replace the reflectors in the RPM's (castings) periodically to maintain an acceptable level of position guidance for the motoring public through the use of pavement lane delineation during inclement weather, especially at night. A general guide for the replacement cycle of the reflectors is based on the ADT volumes as follows:

$\begin{array}{lll}\text { ADT Vehicular Volumes } & \begin{array}{c}\text { Replacem } \\ \text { Cycle }\end{array} \\ \text { 2 lane } & \text { 4 or more lanes } & \\ \text { less than } 5,000 & \text { less than } 10,000 & 4 \text { Years } \\ 5,000 \text { to } 15,000 & 10,000 \text { to } 30,000 & 3 \text { Years } \\ \text { greater than } 15,000 & \begin{array}{l}30,000 \text { to } 75,000 \\ \text { greater than } 75,000\end{array} & 2 \text { Years } \\ & \text { 2 Years }\end{array}$

The above replacement cycle is based on the corresponding traffic volumes (ADT) and is only an estimate which must be verified by inspection prior to including the section of highway in the next RPM maintenance contract. The inspection should include a consideration of : a) the number of broken reflectors; b) the effectiveness of the reflectivity of the un-broken reflectors; and, c) the number of missing or damaged RPM castings. The higher volume roadways should be inspected periodically to verify the replacement cycle. 
MEMORANDUM - PAGE 2 OF 2

Snowplowable RPM's

Maintenance

April 26, 1996

Roadways, with an ADT in excess of 75,000 , shall be inspected at least once each year. Additional inspections may be necessary if an inspection indicates that the RPM's on the roadway section are approaching conditions for maintenance needs. Complaints, from the public, concerning broken, damaged, or missing reflectors or castings or generally poor night-time visibility of RPM's on the roadway should instigate a supplemental investigation, unless the roadway section has been recently inspected.

If scheduled reconstruction or resurfacing of the section of road being considered for RPM maintenance is likely to occur within a time frame of less than one-half of the replacement cycle, the district may elect to defer the maintenance of the RPM's. Deferral of the maintenance should not occur if lack of maintenance to the RPM's creates or causes a hazard to the motoring public.

Each district shall determine the sections of highway, within it's boundaries, where RPM maintenance is desirable. Starting and ending points, of RPM projects, should occur at natural break-off areas that will not confuse the motorists. Districts shall coordinate their planned RPM maintenance with abutting districts to assure that there is continuity of maintenance along a roadway. District personnel, jointly with Intermodal Transportation Division - Transportation Programming Section, shall develop projects and determine the type of funding for the RPM maintenance contracts.

Each district shall prepare the plans for the RPM maintenance contracts within their district. The plans shall be submitted to the Technical Services Division for further processing and letting.

Each district shall maintain and retain a record system that contains: a) the location of RPM's, b) the number of RPM's, c) date installed initially (if available), and d) the date(s) the RPM's were maintained. In addition, it is suggested, that each district maintain a map that: a) displays the route location, with beginning and ending points; of RPM's, b) when the RPM's were installed or last maintained (by contract), and c) the proposed resurface/reconstruction dates for all roadway sections that have RPM's.

\section{TDB:CTT:ctt}

\author{
cc: Jim Poturalski \\ Homer Unger \\ Sami Mohamed \\ Larry Goode (3)
}

Mike Lindley

Ed Cox

Frank Vukovits

Traffic Field Engineers (3) 